\title{
KETTLE HOLES IN THE AGRARIAN LANDSCAPE: ISOLATED AND ECOLOGICAL UNIQUE HABITATS FOR CARABID BEETLES (COL.: CARABIDAE) AND SPIDERS (ARACH.: ARANEAE)
}

\author{
RALPH PlateN ${ }^{1}$, THOMAS KALETTKA ${ }^{2}$, CHRISTIAN UlRICHS ${ }^{3}$ \\ ${ }^{I}$ Institute of Land Use Systems, Leibniz Center of Agricultural Landscape Research \\ (ZALF), Eberswalder Straße 84, 15374 Müncheberg, e-mail: platen@zalf.de \\ ${ }^{2}$ Institute of Landscape Hydrology, Leibniz Center of Agricultural Landscape Research \\ (ZALF), Eberswalder Straße 84, 15374 Müncheberg, e-mail: tkalettka@zalf.de \\ ${ }^{3}$ Division Urban Plant Ecophysiology, Life Sciences Faculty, Humboldt-Universität zu \\ Berlin, Lentzeallee 55-57, 14195 Berlin,e-mail: christian.ulrichs@hu-berlin.de
}

Received: $22^{\text {nd }}$ March 2016, Accepted: $31^{\text {st }}$ May 2016

\begin{abstract}
Kettle holes are small depressional wetlands and because of the high variability of site factors they are potential hotspots of biodiversity in the monotone arable land. We investigated eight kettle holes and two agrarian reference biotopes for carabid beetles and spiders. The animals were captured with pitfall traps from May to August 2005, along with surveys of the soil and vegetation. We asked whether each kettle hole has specific ecological properties which match with characteristic carabid beetle and spider coenoses and whether they represent isolated biotopes. Differences in the composition of ecological and functional groups of carabid beetles and spiders between the plots were tested with an ANOVA. The impact of the soil variables and vegetation structure on the distribution of species was analyzed with a Redundancy Analysis. The assemblage similarities between the kettle hole plots were calculated by the Wainstein-Index. Ecological groups and habitat preferences of carabid beetles had maximal expressions in seven different kettle holes whereas most of the ecological characteristics of the spiders had maximal expression in only two kettle holes. High assemblage similarity values of carabid beetle coenoses were observed only in a few cases whereas very similar spider coenoses were found between nearly all of the kettle holes. For carabid beetles, kettle holes represent much more isolated habitats than that for spiders. We concluded that kettle holes have specific ecological qualities which match with different ecological properties of carabid beetles and spiders and that isolation effects affect carabid beetles more than spiders.
\end{abstract}

Keywords: agrarian landscape, ecological group, habitat preference, landscape ecology, migration, wetland

\section{INTRODUCTION}

Kettle holes in the agrarian landscape are like a negative print of islands in the ocean - they represent wet islands within the predominantly dry arable land surrounding them. From the scientific point of view, kettle holes are glacially created small standing water bodies 
Platen R., Kalettka T., Ulrichs Ch.: Kettle holes in the agrarian landscape: Isolated and ecological unique habitats for Carabid beetles (Col.: Carabidae) and spiders (Arach.: Araneae)

( $\leq 1 \mathrm{ha}$ ), which act as depressional wetlands and mostly undergo a wet-dry cycle. They are spread widely in the agrarian and woody landscapes of young moraine regions in Northern Europe (Bosiacka \& Pienkowski 2012; Gerke et al., 2010; Kalettka et al., 2001; Kalettka \& Rudat, 2006; Waldon, 2012) and Northern America (Euliss et al., 2008; Gleason et al., 2011).

Kettle holes are characterized by a high variability of site factors, and therefore are potential hotspots of structural and biological diversity. The vegetation and fauna of kettle holes is often much more diversified compared to the biota of the surrounding monotone arable land. However, over the last 60 years many kettle holes have become subject to intensive agricultural land use practices and active removal, which has caused severe pollution, structural degradation and decrease of biodiversity. But, many kettle holes are still important biotopes, that contribute to biodiversity in the agrarian landscape (Lischeid \& Kalettka, 2012; Niedringhaus \& Zander, 1998; Pätzig et al., 2012; Waldon, 2012; Pienkowski, 2000).

Whereas the topography, genesis and use of kettle holes in Northeast Germany have been investigated over a long time (Kalettka, 1996; Kalettka et al., 2001), awareness of the ecological value of kettle holes and other small water bodies has only recently been increasing (Boix et al., 2012). Kettle holes have been studied and characterized in terms of hydrogeomorphological properties (Gerke et al., 2010; Kalettka \& Rudat, 2006; Schindler 1996), limnology (Greulich \& Schneeweiss, 1996; Haacke et al,. 1996; Lischeid \& Kalettka, 2012; Kleeberg et al., 2015), macrophytes (Luthardt \& Dreger, 1996; Pätzig et al., 2012; Waldon, 2012), amphibians (Greulich \& Schneeweiss, 1996; Schneeweiss, 1996; Berger et al,. 2010), and conservation and management (Frielinghaus, 1996; Kalettka, 1996; Berger et al., 2010). DeMeester et al. (2005) recommend the study of ponds and pools as model systems for ecology, evolutionary biology and conservation biology because of their great variability in types, and abiotic gradients. This allows for study of the relations between their characteristics in biodiversity, assemblage composition, food webs and ecological gradients. Because of their small size they are often severely threatened by human activities such as agricultural management and thus may serve as an early warning system for long-term ecological changes. Scheffer et al. (2006) state that in contrast to the often argued point that due to isolation shallow lakes and ponds are not rich in species, small water bodies often contain species-rich communities of specific groups of organisms, e.g., submerged plants and invertebrates. The authors suggest that the connection of isolated habitat fragments may sometimes lead to a loss of species diversity and thus decrease rather than enhance landscape-level biodiversity.

For kettle holes, there are only a few studies on invertebrate fauna (Niedringhaus \& Zander, 1998; Kleeberg \& Schmidt, 1999; Brose, 2001, 2003a,b). However, because of their species richness and diverse ecological requirements, invertebrate fauna is well suited to characterize the ecological singularities of the kettle holes compared to the circumjacent arable fields. However, besides the papers of Brose (2001, 2003a, b), there are no systematic field studies published on carabid beetles and spiders of kettle holes in Germany. Kleeberg \& Schmidt (1999) and Schmidt (2005) provide brief species lists of carabid beetles collected from kettle holes in the federal countries of Brandenburg and Mecklenburg-Vorpommern.

Our study intends to extend the knowledge about the invertebrate fauna of kettle holes and to describe them as unique wet spots in the agrarian landscape. The objective of our investigation is to highlight differences in species composition and the composition of ecological and functional groups of carabid beetle and spider assemblages of the kettle holes, and to investigate the differences between kettle holes of different hydrogeomorphological types and agrarian reference habitats. Furthermore, we wanted to find evidence that there is 
an isolation effect for the carabid beetle and spider assemblages between the kettle holes, and that this isolation effect impacts the two animal groups differently. We will discuss whether differences in the migration mode of carabid beetles and spiders lead to isolation effects. Our hypotheses are that abiotic factors and the vegetation structure explain most of the variance of species composition at the kettle holes and the agrarian reference habitats. Furthermore, we assume that each kettle hole has a unique setting of site factors that bear specific carabid beetle and spider coenoses with specific ecological traits and habitat preferences. Finally and to a different extend kettle holes represent spatially isolated habitats for carabid beetle and spider assemblages.

\section{MATERIALS AND METHODS}

\section{Hydrogeomorphic types of kettle holes}

The kettle holes of northeast Brandenburg were typed by Kalettka \& Rudat (2006). A total of 144 kettle holes exhibiting different hydrological and morphological variables were assigned to five different hydrogeomorphological (HGM) classes (Figure 1). Eight from these 144 kettle holes of different HGM types were selected for investigation in this study (see labels in Figure 1).

Fig. 1: The hydrogeomorphological types of kettle holes in Northeast Brandenburg (Kalettka \& Rudat, 2006) with labels of the eight kettle holes investigated in this study

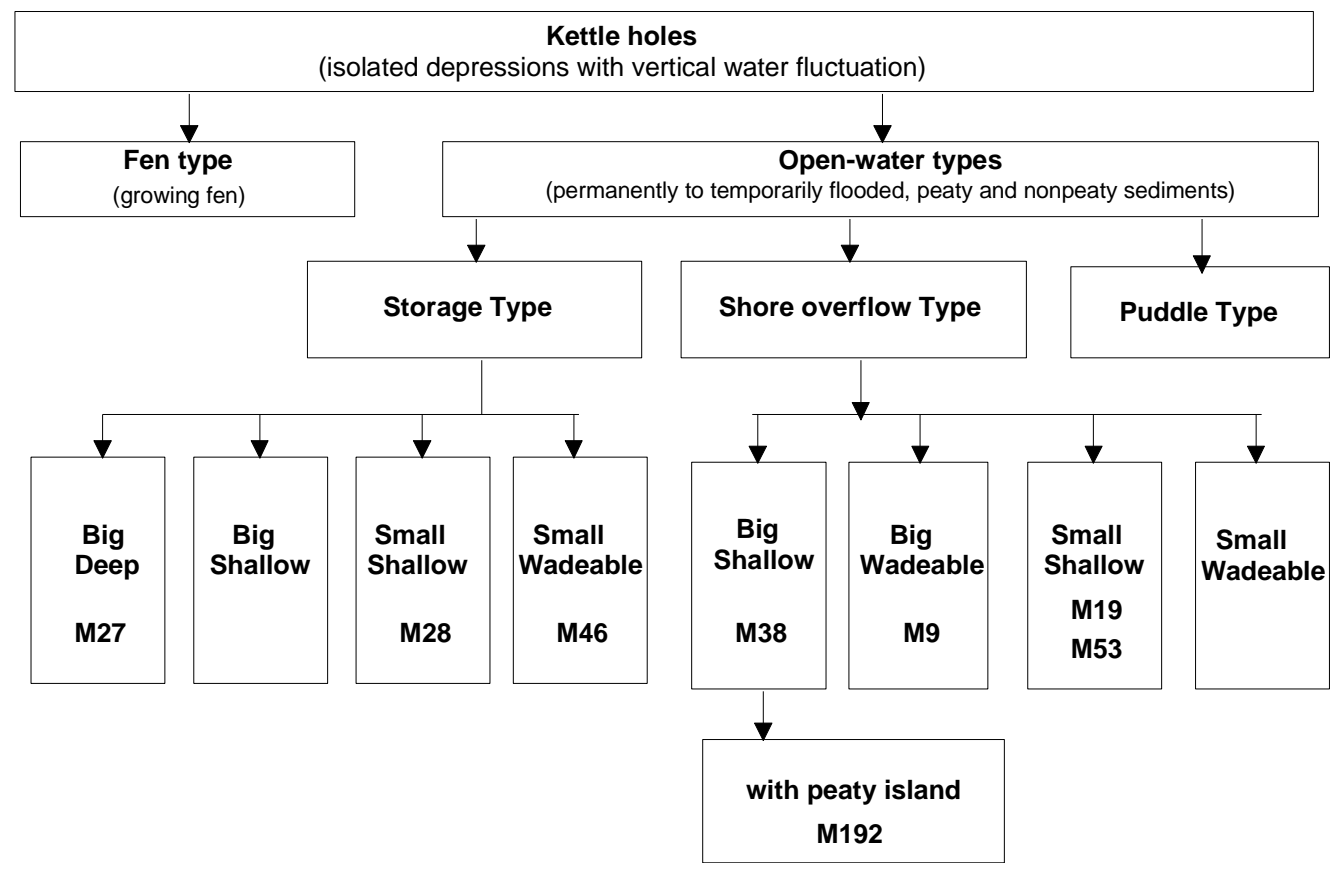

\section{Study area}

Our study was comprised eight selected kettle holes of different hydrogeomorphical types (Figure 1), and two agrarian reference biotopes (see Table A1 for description), situated south of the city of Müncheberg in the young moraine landscape of the northeastern plain of Germany. The soils of the area are predominantly sandy. The annual precipitation ranges between 357 and $793 \mathrm{~mm}^{*} \mathrm{a}^{-1}$, and the average temperature is $8.8^{\circ} \mathrm{C}$. (Meteorological station 
Müncheberg 1973-2002; Federal Ministry of Transport, Building and Urban Development, Deutscher Wetterdienst, 2011, unpublished data). The nomenclature of the examined kettle holes followed an internal catalogue (Kalettka, unpublished data) with the letter "M" designating the region of Müncheberg and a number specifying the location. As reference sites, we examined a barley field (MuA62) and a dry set-aside (MuS05) in the vicinity of the investigated kettle holes.

\section{Capture design and species identification}

The carabid beetles and ground dwelling spiders were captured in pitfall traps (Barber, 1931). At each plot, five traps with an upper diameter of $6.5 \mathrm{~cm}$ were arranged in a straight line at a distance of $5 \mathrm{~m}$ from each other. The killing and preserving fluid consisted of Ethanol (70 \%) and acetic acid (90\%) at a proportion of 7:1 with water added to $1 \mathrm{~L}$.

From April $28^{\text {th }}$ to August $31^{\text {st }} 2005$, the traps were operated and changed every fortnight. The contents of the traps were carried to the laboratory, transferred to $70 \%$ ethanol, and stored at $4{ }^{\circ} \mathrm{C}$ until ready for examination. For each single trap, the animals were identified to the species level. At the barley field the traps could not be operated between July $06^{\text {th }}$ and July $20^{\text {th }}$ and between August $17^{\text {th }}$ and August $31^{\text {st }}$ due to harvesting and ploughing.

The carabid beetles were identified by Heidi Riedel based on Müller-Motzfeld (2004) and the spiders by Ralph Platen based on Heimer \& Nentwig, (1991); Roberts (1985, 1987, 1995); and Wiehle (1956, 1960). Specimen copies are deposited at the collection of the Institute of Land Use Systems at the Leibniz Centre of Agricultural Landscape Research (ZALF). The ecological data for carabid beetles were drawn from the catalogue of the Gesellschaft für angewandte Carabidologie (GAC 2009, modified); Larsson (1939) and Lindroth (1992a, b), and for the spiders the data were drawn from Platen et al. (1991, 1999, modified). The nomenclature follows Köhler \& Klausnitzer (2014) for carabid beetles and Platnick (2013) for spiders. Bembidion mannerheimii C.R. Sahlberg and Bembidion neresheimeri J. Müller were not distinguished.

\section{Soil analyses}

On June $29^{\text {th }}$ and October $06^{\text {th }} 2005$, soil cores were collected with a $100 \mathrm{~cm}^{3}$ volume cylinder at each plot. The soil acidity was measured based on the $\mathrm{pH}$ at $22{ }^{\circ} \mathrm{C}$, by mixing $10 \mathrm{~g}$ of soil with a suspension of $0.01 \mathrm{~N} \mathrm{CaCl}_{2}$ and then homogenized with a mechanical shaker for $30 \mathrm{~min}$. The soil texture was determined with a set of soil sieves with mesh widths of 0.63 , 0.2 and $0.063 \mathrm{~mm}$ after drying $100 \mathrm{~g}$ of the soil at $105^{\circ} \mathrm{C}$ for $24 \mathrm{~h}$. Each soil fraction was weighed separately. The loss of ignition was determined by burning up to $5 \mathrm{~g}$ of dry soil in a porcelain cup at $450{ }^{\circ} \mathrm{C}$ for $24 \mathrm{~h}$. The remaining inorganic material was weighed and calculated as the percentage of the initial weight. Afterwards, the percentage of organic material was calculated. The water volume was determined by drying the soil within a $100 \mathrm{~cm}^{3}$ core cylinder for $24 \mathrm{~h}$ at $105^{\circ} \mathrm{C}$ (all of the methods were according to Schlichting et al., 1995).

\section{Vegetation surveys}

Vegetation surveys were performed according to the Braun-Blanquet estimation scale (Dierschke, 1994) twice at each plot, on May $30^{\text {th }}$ and July $26^{\text {th }}, 2005$ and on five areas of $5 \mathrm{~m}^{2}$ with a distance of $1 \mathrm{~m}$ apart from the pitfall traps. Along with the cover values of the plant species, the vegetation structure - vegetation height, herb and grass cover and the percentage of bare ground were visually estimated. The environmental variables at each plot are summarized in Table A1 in the appendix. 


\section{Classification and analyses of ecological data}

The carabid beetle and arachnid species caught were characterized by ecological and functional traits. The ecological traits characterize the species' preferences towards abiotic factors, i.e. humidity, light exposure, and temperature in the field. These traits are summarized in the ecological group (EG). The data for carabid beetles were drawn from Barndt et al. (1991) and for arachnids from Platen et al. (1991). The functional traits were assigned to different functional groups: The habitat preferences (HP) for carabid beetles were based on the catalogue of the GAC (2009) with regard to the north-eastern lowland of Germany. The corresponding habitat preferences for arachnids were based on Platen et al. (1991, modified) (Tables A3 and A4). The wing morphology (WM) and hibernation modes (HM) for carabid beetles were taken from Larsson (1939) and Lindroth (1992). The individual body mass of the carabid beetle species was calculated with the formula of Jarosik (1989) and divided into five body mass classes (BMC). For spiders the individual body masses were calculated by the formula of Henschel et al. (2006), which were also divided into five body mass classes (Tables A3 and A4).

\section{Statistical analyses}

Before the statistical analyses, the individuals of each species were summed up for each trap for the entire investigation period. The impact of the environmental variables on the species composition was analyzed by a Redundancy Analysis (RDA) (Braak \& Smilauer, 2002). Kettle hole M192 was not included in the analysis for carabid beetles, because too few animals were caught. The characteristic hydrogeomorphological features, area, average water depth and slope inclination that were essential for the assignment to the different classes were first included in the analyses but were removed because no significant impact on the species composition was found. Before the analyses, the species data were Hellinger transformed (Legendre \& Gallagher, 2001). The following environmental variables were included in the RDA: water volume, four soil fractions, $\mathrm{pH}$, the portion of organic material, the height and total coverage of the vegetation and the proportion of bare ground. Differences in the ArcSinSqrt- transformed percentage number of individuals of ecological and functional groups of the carabid beetle and spider coenoses between the kettle hole and the reference plots were calculated by a one-way ANOVA. Subsequently, the significance was determined by a Duncan-Test ( $\leq 0.05$ ) for pairwise comparison (Sokal \& Rohlf, 2012). The transformed data were tested to normal distribution by the Kruskal-Wallis Test and for homoscedasticity by the Levene-Test. The assemblage similarity was calculated by the Wainstein-Index (Mühlenberg, 1993).

The computer programs that were used were the Web-App Biometrie Andersson-Info Anderßon \& Anderßon (2015), CANOCO Vers. 4.5 (Braak \& Smilauer, 2002) and SPSS Vs. 19 (IBM Corp., Armonk, NY, USA).

\section{RESULTS}

\section{General}

In total, 11,136 individuals out of 114 carabid beetle species and 119 species of spiders from 17,216 individuals were caught (Table 1). For lists of the species with detailed information on the ecology see Tables A2 and A3.

The highest number of carabid beetle species was found at kettle hole M46. The highest number of individuals occurred at the set-aside MuS05 was nearly 2,000 individuals. Only $5 \%$ of this number of individuals was caught at the peaty kettle hole M192. At this site, also the lowest number of species also occurred which was five times lower than in M46. 
Platen R., Kalettka T., Ulrichs Ch.: Kettle holes in the agrarian landscape: Isolated and ecological unique habitats for Carabid beetles (Col.: Carabidae) and spiders (Arach.: Araneae)

Table 1: Numbers of species and individuals carabid beetles and spiders at the plots investigated. For the explanation of the abbreviations of the plots see chapter 2.1.

$\mathrm{SE}=$ Standard error. Dark grey shaded cells indicate the highest numbers, whereas light grey shaded cells represent the lowest numbers.

\begin{tabular}{lrrrrrrrrrr}
\hline Carabidae & M9 & SE & M19 & SE & M27 & SE & M28 & SE & M38 & SE \\
\hline Spec. & 64 & 2.43 & 53 & 1.63 & 56 & 2.38 & 67 & 1.12 & 47 & 3.07 \\
Ind. & 1,773 & 38.33 & 678 & 22.88 & 1,123 & 29.30 & 610 & 14.26 & 495 & 13.27 \\
\hline Spiders & M9 & SE & M19 & SE & M27 & SE & M28 & SE & M38 & SE \\
\hline Spec. & 54 & 1.63 & 45 & 1.63 & 47 & 1.94 & 65 & 2.14 & 44 & 1.57 \\
Ind. & 1,897 & 21.69 & 1,254 & 37.40 & 1,909 & 63.95 & 2,221 & 51.83 & 1,236 & 37.76 \\
\hline
\end{tabular}

\begin{tabular}{|c|c|c|c|c|c|c|c|c|c|c|}
\hline Carabidae & M46 & $\mathrm{SE}$ & M53 & $\mathrm{SE}$ & M192 & $\mathrm{SE}$ & MuS05 & SE & MuA62 & SE \\
\hline Spec. & 71 & 2.28 & 58 & 1.28 & 14 & 1.79 & 46 & 1.72 & 35 & 0.74 \\
\hline Ind. & 1,938 & 35.38 & 856 & 8.48 & 100 & 4.18 & 1,968 & 54.58 & 1,595 & 11.60 \\
\hline Spiders & M46 & $\mathrm{SE}$ & M53 & SE & M192 & SE & MuS05 & SE & MuA62 & SE \\
\hline Spec. & 46 & 1.47 & 55 & 1.40 & 44 & 2.85 & 40 & 1.67 & 28 & 1.77 \\
\hline Ind. & 2,614 & 106.47 & 1,963 & 22.77 & 997 & 25.00 & 2,291 & 64.83 & 834 & 24.07 \\
\hline
\end{tabular}

For spiders, the highest number of species occurred at M53 and the lowest number at the barley-field MuA62. This is where the lowest number of individuals also appeared which was nearly two times lower than at M53. The number of individuals was three times lower than at M46 (Table 1).

\section{The impact of environmental variables on species composition of carabid beetle and spider assemblages}

To determine the impact of soil and vegetation structure variables on the species composition of the carabid beetle and spider assemblages at the kettle hole and reference plots, Redundancy Analyses (RDA) were performed (Figures 2 and 3; Table 2). The species data at all the kettle holes were included into the analyses but the results for the kettle hole M192 could not be displayed properly in the RDA-diagram for carabid beetles because of its extreme outlier position because only a hundred individuals out of 14 carabid beetle species were caught there. Except for the barley field MuA62, the carabid beetle assemblages of the single plots were very heterogeneous (Figure 2). This may be due to the position of the single traps of the plots which are sometimes greatly separated from each other. The water volume had the greatest impact (due to the length of the arrow) together with organic matter and vegetation (due to their close vicinity to the first axis) on the right hand side. The gradient of 
the variable water volume points towards the wettest kettle hole M38, the extension in the opposite direction points to the driest plots MuS05 and MuA62 (for exact values: see Table A1). The gradients organic matter and the herb and grass coverages also point to the right, where most of the kettle plot pitfall traps are displayed. In addition, the gradient "coarse sand" also points to the right, which is due to the high portion of this soil fraction in M38 (Table A1).

Fig. 2: The impact of the environmental variables on the composition of the carabid beetle assemblages. An ordination diagram on the basis of a Redundancy Analysis (RDA).

Grass $=$ cover grass layer, Herb $=$ cover herb layer, $\mathrm{CoSa}=$ coarse sand, $\mathrm{MeSa}=$ medium sand, $\mathrm{FiSa}=$ fine sand, org= percentage organic matter, and WV= water volume. For a legend of the abbreviations in the plots: see Chapter 2.1. The numbers of single traps follow the name of the plots. For a legend of the abbreviations in the species: see Table A2. Horizontal axis: 1st, vertical axis: 2nd canonical axis. Species with a $<30 \%$ variance explanation are not plotted in the figure.

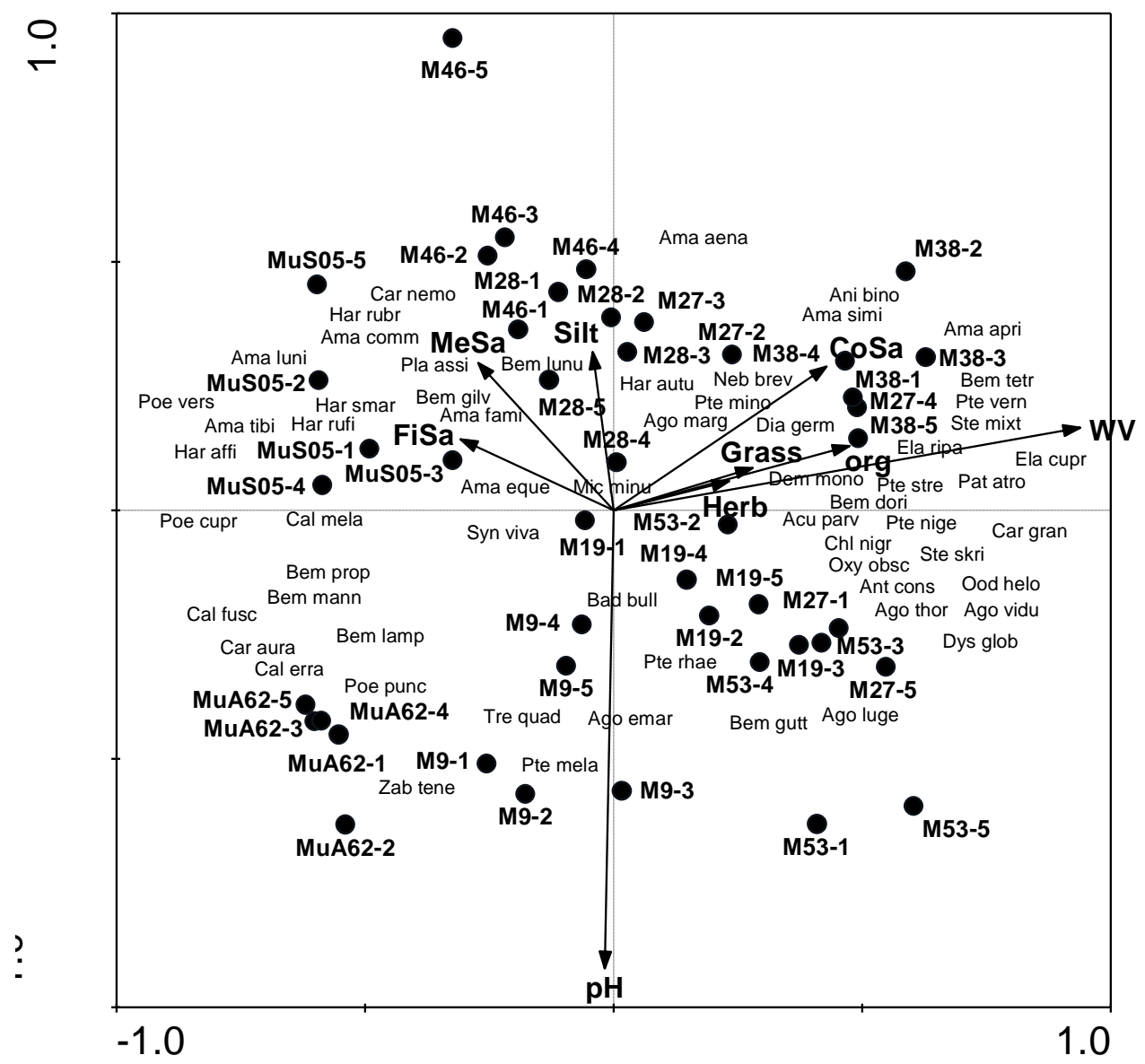

The arrows of the remaining soil fractions point to the left, where the plots on mineral soil MuS05 and MuA62 are present. 
Platen R., Kalettka T., Ulrichs Ch.: Kettle holes in the agrarian landscape: Isolated and ecological unique habitats for Carabid beetles (Col.: Carabidae) and spiders (Arach.: Araneae)

Table 2: The variance explanation in the carabid beetle and spider species data by the environmental variables (relative numbers).

EnVar= environmental variables, $\mathrm{FiSa}=$ fine sand, $\mathrm{MeSa}=$ medium sand, $\mathrm{Herb}=$ cover herb layer, Grass $=$ cover grass layer, org $=$ percentage organic matter, $\mathrm{CoSa}=$ coarse sand, WV= water volume, $\mathrm{VarExpl}=$ variance explanation, Total $=$ total variance explanation by all of the environmental variables

\begin{tabular}{lllllllllll}
\hline & \multicolumn{10}{c}{ Carabid beetles } \\
\hline EnvVar & Silt & FiSa & MeSa & Herb & pH & Grass & org & CoSa & WV & Total \\
\hline VarExpl & 0.02 & 0.04 & 0.04 & 0.05 & 0.06 & 0.06 & 0.07 & 0.07 & 0.22 & 0.47 \\
\hline & & & \multicolumn{10}{c}{ Spiders } \\
\hline EnvVar & $\mathrm{pH}$ & Silt & Herb & org & FiSa & CoSa & MeSa & WV & Grass & Total \\
\hline VarExpl & 0.01 & 0.01 & 0.04 & 0.04 & 0.05 & 0.06 & 0.09 & 0.09 & 0.11 & 0.40 \\
\hline
\end{tabular}

All of the environmental variables explain nearly one half of the variance in the species data, and the water volume contributes to nearly one half of the total variance explanation (Table 2).

The carabid beetle coenoses are well separated from each other, and arable field species are displayed near MuA62 (Bembidion lampros (Herbst), B. properans (Stephens), Carabus auratus Linné, and Zabrus tenebrioides (Goeze)), meadow and dry grassland species near MuS05 (Poecilus versicolor (Sturm), Amara communis (Panzer), A. lunicollis Schiödte, and Harpalus affinis (Schrank)), and wetland species near M38 (Elaphrus cupreus Müller, Patrobus atrorufus (Stroem), Pterostichus vernalis (Panzer), and Stenolophus mixtus (Herbst)). At the remaining kettle holes, except for M46, several species of wet, open habitats are plotted (Agonum ssp., Anthracus consputus (Duftschmid)) which are characteristic of specific kettle holes (M9, M27, M28). For habitat preferences of the species: see Table A2).

For spiders, a RDA with the same constraints as the analysis for carabid beetles was performed (Figure 3). The spider assemblages at the plots appeared to be much more homogeneously distributed all over the plots than those of the carabid beetles (Figure 2) which may be based on the mostly near-by plotted single traps of the specific plots. Thus, apart from the very wet (M38 at the bottom, M192 to the right) kettle holes and the dry set-aside MuS05 at the top, the remaining plots are much more crowded together near the center of the ordination diagram, which indicates that the all-together similarity of the spider assemblages of all of the plots considered is greater than that of the carabid beetle assemblages (compare Figure 3 with Figure 2, and see chapter 3.4). For spiders the peaty kettle hole M192 was included in the RDA diagram which resulted in an "outcast" position of M192 due to its deviant assemblage and a subsequent "compression" of the remaining kettle hole plot positions. 
Fig. 3: The impact of the environmental variables on the composition of the spider assemblages. An ordination diagram on the basis of a Redundancy Analysis (RDA).

Grass $=$ cover grass layer, Herb $=$ cover herb layer, $\mathrm{CoSa}=$ coarse sand, $\mathrm{MeSa}=$ medium sand, $\mathrm{FiSa}=$ fine sand, org= percentage organic matter, and WV= water volume. For a legend of the abbreviations in the plots: see Chapter 2.1. The numbers of single traps follow the name of the plots. For a legend of the abbreviations in the species: see Table A3. Horizontal axis: 1st, vertical axis: 2nd canonical axis. Species with a $<30 \%$ variance explanation are not plotted in the figure.

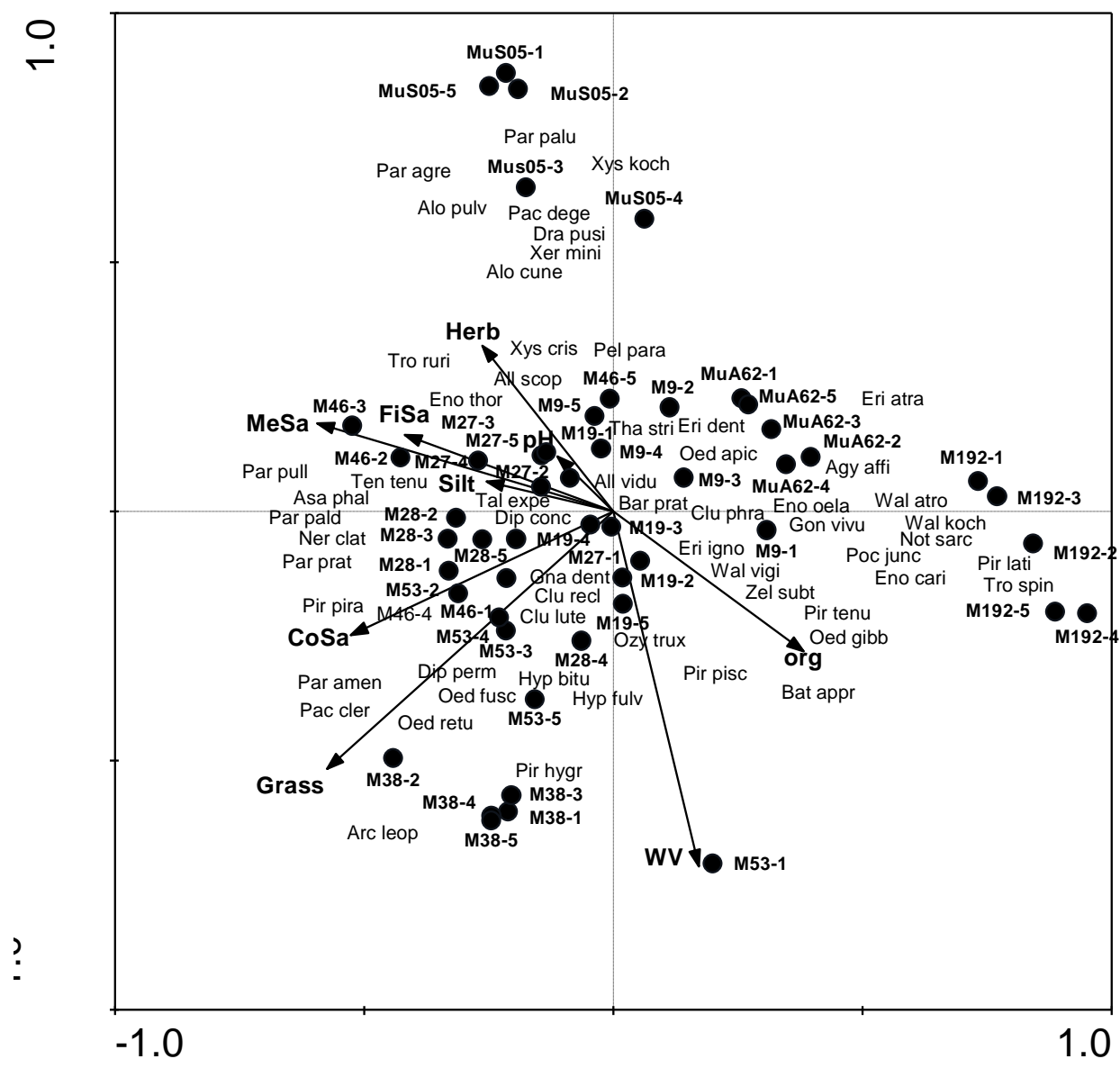

Similar to the carabid beetles, the arrows of the gradients water volume and coarse sand points towards M38 (and one trap of M53) (Figure 3), but the arrow of the gradient organic matter points in the direction of the additional plot M192, with soils consisting of almost entirely peat.

Altogether, the environmental variables explain $40 \%$ of the variance in the species data, where the cover of the grass layer contributes $11 \%$. Diverging from the results for carabid beetles, the water volume contributes to only $9 \%$ of the total variance (Table 2). The kettle hole with peaty island M192 bears a moor-typical spider assemblage (Enoplognatha caricis (Fickert), Notioscopus sarcinatus (O.P.-Cambridge), Walckenaeria kochi (O.P.-Cambridge)), whereas at the plot MuS05 meadow- and dry grassland species agglomerate (Alopecosa pulverulenta (Clerck), Pardosa palustris (Linnaeus), Xerolycosa miniata (C.L. Koch)). At the barley field MuA62, arable field species are the predominantly 
occurrence (Erigone ssp., Oedothorax apicatus (Blackwall)), whereas at the remaining plots the species are displayed close to the center and thus occur with similar quantities at the plots displayed. For habitat preferences of the species: see Table A3).

\section{Ecological and functional groups}

Differences in the composition of the carabid beetle and spider assemblages with regard to their ecological and functional groups were calculated by a one-way ANOVA. Whilst the carabid beetles had maximal values of the proportions of individuals of different ecological and functional groups in every kettle hole (except for M27), the correspondent numbers for spiders concentrated primarily in three kettle holes. Within a block of four kettle holes, no maximal and minimal values occurred (Table 3 ). The maximum and minimum values for the ecological groups and the habitat preferences do not always match well with the measured abiotic variables (Table A1).

Table 3: The composition of the carabid beetle assemblages were classified according to ecological and functional groups. The average percentage of individuals per trap and year (ArcSin SQRT transformed).

The letters a, b, c, d, e, f indicate statistically significant differences (Duncan-Test, $\mathrm{p}<0,05$ ). BMC= body mass class. For the abbreviations of the Roman numerls see Table A2

\begin{tabular}{|c|c|c|c|c|c|c|c|c|}
\hline Parameters & M9 & M19 & M27 & M28 & M38 & M46 & M53 & M192 \\
\hline hygrophilic & $21.8^{\mathrm{a}, \mathrm{b}, \mathrm{c}}$ & $22.2^{\mathrm{a}, \mathrm{b}, \mathrm{c}}$ & $21.4^{\mathrm{a}, \mathrm{b}, \mathrm{c}}$ & $25.4^{\mathrm{a}, \mathrm{b}}$ & $17.6^{\mathrm{b}, \mathrm{c}}$ & $23.6^{\mathrm{a}, \mathrm{b}, \mathrm{c}}$ & $28.9^{\mathrm{a}}$ & $15.3^{\mathrm{c}}$ \\
\hline $\begin{array}{l}\text { predominantly } \\
\text { hygrophilic }\end{array}$ & $13.2^{\mathrm{b}, \mathrm{c}}$ & $13.4^{\mathrm{b}, \mathrm{c}}$ & $8.4^{\mathrm{c}}$ & $16.1^{\mathrm{b}}$ & $25.2^{\mathrm{a}}$ & $14.1^{\mathrm{b}, \mathrm{c}}$ & $9.7^{\mathrm{b}, \mathrm{c}}$ & $0.0^{\mathrm{d}}$ \\
\hline xerophilic & $10.1^{\mathrm{d}}$ & $10.9^{\mathrm{d}}$ & $13.9^{\mathrm{c}, \mathrm{d}}$ & $16.1^{\mathrm{c}}$ & $32.7^{\mathrm{a}}$ & $21.9^{\mathrm{b}}$ & $9.1^{\mathrm{d}}$ & $2.4^{\mathrm{e}}$ \\
\hline eurytopic & $35.8^{\mathrm{b}, \mathrm{c}}$ & $43.4^{\mathrm{a}}$ & $30.6^{\mathrm{c}, \mathrm{d}}$ & $24.7^{\mathrm{d}, \mathrm{e}}$ & $22.7^{\mathrm{e}}$ & $41.7^{\mathrm{a}, \mathrm{b}}$ & $41.7^{\mathrm{c}}$ & $5.4^{\mathrm{f}}$ \\
\hline arable fields & $29.2^{\mathrm{a}}$ & $11.9^{\mathrm{b}}$ & $16.1^{\mathrm{b}}$ & $12.5^{\mathrm{b}}$ & $18.8^{\mathrm{b}}$ & $33.8^{\mathrm{a}}$ & $18.0^{\mathrm{b}}$ & $5.4^{\mathrm{c}}$ \\
\hline $\begin{array}{l}\text { meadows and } \\
\text { pastures }\end{array}$ & $16.0^{\mathrm{c}}$ & $16.8^{\mathrm{c}}$ & $9.2^{\mathrm{d}}$ & $19.0^{\mathrm{b}, \mathrm{c}}$ & $23.8^{\mathrm{a}, \mathrm{b}}$ & $26.9^{\mathrm{a}}$ & $9.3^{\mathrm{d}}$ & $0.0^{\mathrm{e}}$ \\
\hline wet, open habitats & $38.8^{\mathrm{a}, \mathrm{b}, \mathrm{c}}$ & $30.6^{b, c}$ & $43.0^{\mathrm{a}, \mathrm{b}}$ & $44.2^{\mathrm{a}, \mathrm{b}}$ & $27.0^{\mathrm{c}}$ & $32.7^{\mathrm{a}, \mathrm{b}, \mathrm{c}}$ & $40.1^{\mathrm{a}, \mathrm{b}, \mathrm{c}}$ & $45.8^{\mathrm{a}}$ \\
\hline dry, open habitats & $4.8^{\mathrm{e}, \mathrm{f}}$ & $9.4^{\mathrm{c}, \mathrm{d}}$ & $13.2^{\mathrm{b}, \mathrm{c}}$ & $15.3^{\mathrm{b}}$ & $29.6^{\mathrm{a}}$ & $15.5^{\mathrm{b}}$ & $8.2^{\mathrm{d}, \mathrm{e}}$ & $2.4^{\mathrm{f}}$ \\
\hline brachypterous & $11.5^{\mathrm{a}, \mathrm{b}}$ & $10.5^{\mathrm{a}, \mathrm{b}}$ & $6.0^{\mathrm{b}, \mathrm{c}}$ & $14.9^{\mathrm{a}}$ & $10.9^{\mathrm{a}, \mathrm{b}}$ & $11.2^{\mathrm{a}, \mathrm{b}}$ & $8.1^{\mathrm{a}, \mathrm{b}, \mathrm{c}}$ & $2.2^{\mathrm{c}}$ \\
\hline dimorphic & $47.3^{\mathrm{a}, \mathrm{b}, \mathrm{c}}$ & $50.5^{\mathrm{a}, \mathrm{b}}$ & $46.1^{\mathrm{a}, \mathrm{b}, \mathrm{c}}$ & $34.7^{\mathrm{c}, \mathrm{d}}$ & $30.7^{\mathrm{d}}$ & $26.1^{\mathrm{d}}$ & $38.6^{\mathrm{b}, \mathrm{c}, \mathrm{d}}$ & $52.9^{\mathrm{a}}$ \\
\hline macropterous & $40.2^{\mathrm{c}, \mathrm{d}}$ & $36.8^{\mathrm{d}}$ & $43.2^{\mathrm{b}, \mathrm{c}, \mathrm{d}}$ & $51.3^{\mathrm{a}, \mathrm{b}, \mathrm{c}}$ & $54.3^{\mathrm{a}, \mathrm{b}}$ & $61.2^{\mathrm{a}}$ & $49.8^{\mathrm{a}, \mathrm{b}, \mathrm{c}, \mathrm{d}}$ & $36.7^{\mathrm{d}}$ \\
\hline spring breeders & $33.2^{\mathrm{a}}$ & $23.3^{\mathrm{b}}$ & $23.7^{\mathrm{b}}$ & $17.9^{\mathrm{b}}$ & $22.6^{\mathrm{b}}$ & $33.4^{\mathrm{a}}$ & $20.7^{\mathrm{b}}$ & $4.4^{\mathrm{c}}$ \\
\hline autumn breeders & $51.4^{\mathrm{c}}$ & $66.0^{\mathrm{b}}$ & $52.9^{c}$ & $68.8^{\mathrm{b}}$ & $64.7^{\mathrm{b}}$ & $54.4^{\mathrm{c}}$ & $68.2^{\mathrm{b}}$ & $85.6^{\mathrm{a}}$ \\
\hline BMC I & $30.8^{\mathrm{b}, \mathrm{c}}$ & $46.7^{\mathrm{a}}$ & $40.4^{\mathrm{a}, \mathrm{b}}$ & $37.7^{\mathrm{a}, \mathrm{b}}$ & $25.3^{\mathrm{c}}$ & $25.9^{\mathrm{c}}$ & $38.7^{\mathrm{a}, \mathrm{b}}$ & $14.6^{\mathrm{d}}$ \\
\hline BMC II & $25.9^{\mathrm{c}, \mathrm{d}}$ & $23.7^{\mathrm{c}, \mathrm{d}}$ & $26,9^{\mathrm{b}, \mathrm{c}, \mathrm{d}}$ & $37.0^{\mathrm{b}}$ & $50.3^{\mathrm{a}}$ & $16.7^{\mathrm{d}}$ & $31.0^{\mathrm{b}, \mathrm{c}}$ & $21.8^{\mathrm{c}, \mathrm{d}}$ \\
\hline BMC III & $29.5^{\mathrm{b}}$ & $21.6^{\mathrm{b}, \mathrm{c}}$ & $27.6^{\mathrm{b}, \mathrm{c}}$ & $23.5^{\mathrm{b}, \mathrm{c}}$ & $15.5^{\mathrm{c}}$ & $53.8^{\mathrm{a}}$ & $27.7^{\mathrm{b}, \mathrm{c}}$ & $60.5^{\mathrm{a}}$ \\
\hline BMC IV & $31.8^{\mathrm{a}}$ & $21.0^{\mathrm{b}, \mathrm{c}}$ & $21.8^{\mathrm{b}}$ & $14.1^{\mathrm{d}}$ & $15.5^{\mathrm{c}, \mathrm{d}}$ & $13.0^{\mathrm{d}}$ & $18.2^{\mathrm{b}, \mathrm{c}, \mathrm{d}}$ & $2.3^{\mathrm{e}}$ \\
\hline
\end{tabular}

For example, in one of the wettest kettle holes (M38), xerophilic carabid beetles and those that prefer dry open habitats have maximal numbers of individuals (Table 3). However, the number of individuals of carabid beetles that prefer wet, open habitats had minimal numbers. 
This may be because the portions of coarse and medium sand also had high values at M38 (Table A1). The most consistent results can be seen at M46. The sandy soil fractions and the grass cover had maximum values whereas the soil moisture is rather low. Coincidently, the numbers of individuals of the arable field and grassland species were maximal. Due to the very low numbers of species and individuals at the peaty kettle hole M192, most of the values, except for the number of individuals of species preferring wet, open habitats were negligible (Table 3).

The results for spiders are more consistent (Table 4). In M9, where the lowest value of soil moisture was measured, the highest numbers of individuals of xerophilic and arable field species were present.

At M19, a kettle hole that is rather wet and has a large extent of grass coverage, the numbers of individuals of hygrophilic and grassland spiders and those that prefer wet, open habitats is maximal. At M192 ombrophilic and forest species were the maxima (Table 4). Most of the minimal values appeared in M192.

Table 4: The composition of the spider assemblages were classified according to ecological and functional groups. The average percentage of individuals per trap and year (ArcSin SQRT transformed).

The letters a, b, c, d indicate statistically significant differences (Duncan-Test, $\mathrm{p}<0,05$ ). BMC $=$ body mass class. For the abbreviations of the Roman numerls see Table A3

\begin{tabular}{lcccccccc}
\hline Parameters & M9 & M19 & M27 & M28 & M38 & M46 & M53 & M192 \\
\hline hygrophilic & $65.6^{\mathrm{a}, \mathrm{b}, \mathrm{c}}$ & $69.5^{\mathrm{a}}$ & $61.9^{\mathrm{b}, \mathrm{c}, \mathrm{d}}$ & $60.4^{\mathrm{c}, \mathrm{d}, \mathrm{e}}$ & $56.0^{\mathrm{e}, \mathrm{f}}$ & $57.9^{\mathrm{d}, \mathrm{e}, \mathrm{f}}$ & $67.5^{\mathrm{a}, \mathrm{b}}$ & $52.9^{\mathrm{f}}$ \\
xerophilic & $17.8^{\mathrm{a}}$ & $13.2^{\mathrm{b}}$ & $9.1^{\mathrm{c}}$ & $8.0^{\mathrm{c}}$ & $8.9^{\mathrm{c}}$ & $13.0^{\mathrm{b}}$ & $13.4^{\mathrm{b}}$ & $7.5^{\mathrm{c}}$ \\
ombrophilic & $15.8^{\mathrm{d}}$ & $15.1^{\mathrm{d}}$ & $26.2^{\mathrm{c}}$ & $28.2^{\mathrm{b}, \mathrm{c}}$ & $32.4^{\mathrm{a}}$ & $28.6^{\mathrm{b}, \mathrm{c}}$ & $17.7^{\mathrm{d}}$ & $35.8^{\mathrm{a}}$ \\
arable fields & $19.6^{\mathrm{a}}$ & $13.8^{\mathrm{b}, \mathrm{c}}$ & $11.2^{\mathrm{c}, \mathrm{d}}$ & $9.5^{\mathrm{c}, \mathrm{d}}$ & $11.2^{\mathrm{c,d}}$ & $11.6^{\mathrm{c}, \mathrm{d}}$ & $16.4^{\mathrm{a}, \mathrm{b}}$ & $7.2^{\mathrm{d}}$ \\
meadows and & $55.3^{\mathrm{b}}$ & $62.6^{\mathrm{a}}$ & $56.6^{\mathrm{b}}$ & $56.1^{\mathrm{b}}$ & $49.5^{\mathrm{c}}$ & $52.7^{\mathrm{b}, \mathrm{c}}$ & $56.1^{\mathrm{b}}$ & $17.5^{\mathrm{d}}$ \\
pastures & $57.5^{\mathrm{b}, \mathrm{c}}$ & $63.8^{\mathrm{a}}$ & $58.3^{\mathrm{b}, \mathrm{c}}$ & $58.0^{\mathrm{b}, \mathrm{c}}$ & $52.8^{\mathrm{c}, \mathrm{d}}$ & $54.5^{\mathrm{b}, \mathrm{c}, \mathrm{d}}$ & $59.9^{\mathrm{a}, \mathrm{b}}$ & $50.7^{\mathrm{d}}$ \\
wet, open habitats & $15.8^{\mathrm{d}}$ & $15.1^{\mathrm{d}}$ & $26.2^{\mathrm{c}}$ & $28.2^{\mathrm{b}, \mathrm{c}}$ & $32.4^{\mathrm{a}, \mathrm{b}}$ & $28.2^{\mathrm{b}, \mathrm{c}}$ & $17.7^{\mathrm{d}}$ & $35.8^{\mathrm{a}}$ \\
forests & $8.6^{\mathrm{d}}$ & $13.3^{\mathrm{a}, \mathrm{b}}$ & $9.4^{\mathrm{d}}$ & $11.6^{\mathrm{b}, \mathrm{c,d}}$ & $14.5^{\mathrm{a}, \mathrm{b}}$ & $12.5^{\mathrm{a}, \mathrm{b}, \mathrm{c}}$ & $9.7^{\mathrm{c}, \mathrm{d}}$ & $15.4^{\mathrm{a}}$ \\
BMC I & $64.8^{\mathrm{d}}$ & $70.8^{\mathrm{a}, \mathrm{b}, \mathrm{c}}$ & $72.7^{\mathrm{a}, \mathrm{b}}$ & $66.2^{\mathrm{c}, \mathrm{d}}$ & $70.1^{\mathrm{a}, \mathrm{b}, \mathrm{c}}$ & $71.5^{\mathrm{a}, \mathrm{b}}$ & $73.4^{\mathrm{a}}$ & $67.7^{\mathrm{b}, \mathrm{c}, \mathrm{d}}$ \\
BMC II & $19.5^{\mathrm{a}}$ & $12.6^{\mathrm{b}}$ & $12.1^{\mathrm{b}}$ & $18.9^{\mathrm{a}}$ & $11.8^{\mathrm{b}}$ & $12.0^{\mathrm{b}}$ & $11.7^{\mathrm{b}}$ & $6.7^{\mathrm{c}}$ \\
BMC III & & & & & & & & \\
\hline
\end{tabular}

\section{Assemblage similarity}

One method used to determine possible isolation effects is to calculate the assemblage similarity between the kettle hole plots. Here, the Wainstein-Index was used. For carabid beetles, nine kettle hole plots showed an assemblage similarity $>30 \%$, where M9 and M53 exceed this value in four cases, each (Table 5). It is striking that the highest similarity value did not occur between plots M27 and M28 which are no greater than $100 \mathrm{~m}$ apart. The lowest similarity values were calculated for M192 and M38, two kettle holes that are both very wet, however at M192 only a few carabid species and low numbers of individuals were caught. 
Platen R., Kalettka T., Ulrichs Ch.: Kettle holes in the agrarian landscape: Isolated and ecological unique habitats for Carabid beetles (Col.: Carabidae) and spiders (Arach.: Araneae)

Table 5: The percentage assemblage similarity matrix (Wainstein-Indices) calculated for carabid beetles (left) and spiders for all the investigated plots. For the abbreviations of the plots see chapter 2.1. The maximal values are shaded dark grey while the minimal values are light grey.

\begin{tabular}{lccccccccr}
\hline & M9 & M19 & M27 & M28 & M38 & M46 & M53 & M192 & \\
\hline M9 & & 51.7 & 39.1 & 38.6 & 33.4 & 43.5 & 34.5 & 9.7 & M9 \\
M19 & 30.9 & & 53.5 & 46.2 & 35.6 & 56.6 & 32.1 & 8.9 & M19 \\
M27 & 31.9 & 29.2 & & 56.5 & 52.8 & 46.1 & 48.4 & 23.7 & M27 \\
M28 & 38.7 & 31.5 & 33.1 & & 43.1 & 40.6 & 48.9 & 20.8 & M28 \\
M38 & 14.9 & 16.0 & 21.6 & 12.4 & & 38.9 & 45.1 & 17.2 & M38 \\
M46 & 18.6 & 21.3 & 18.2 & 23.1 & 12.4 & & 37.6 & 9.4 & M46 \\
M53 & 38.9 & 32.4 & 38.9 & 35.7 & 16.1 & 16.2 & & 24.6 & M53 \\
M192 & 14.5 & 15.0 & 13.3 & 11.9 & 5.8 & 10.7 & 12.9 & & M192 \\
\hline & M9 & M19 & M27 & M28 & M38 & M46 & M53 & M192 & \\
\hline
\end{tabular}

For spiders, nearly all of the kettle hole plots $(87.5 \%)$, with the exception of the peaty kettle hole M192 show assemblage similarities above $30 \%$ among themselves. The highest values range between $52 \%$ and $57 \%$. The highest values appeared between M46 and M19 and between M27 and M28 which are within close proximity. The lowest values < $10 \%$ of assemblage similarity appeared between M192 and the drier kettle holes M9, M19, and M46 (Table 5, Table A1).

\section{Potential migration ability of carabid beetles}

To explore differences in the potential migration ability of carabid beetles from kettle holes and the reference sites, we calculated the percentages of species and individuals with different wing morphology. In both groups of plots, only a few brachypterous species and individuals were found. The percentage of dimorphic species was approximately $5 \%$ higher at the plots than in the kettle holes, but the number of individuals was twice as high in the latter group (Table 6). 
Table 6: The absolute and percentage of carabid beetle species and individuals of different of wing morphology at the kettle hole and the reference plots.

$\mathrm{N} \mathrm{spec}=$ number of species, $\mathrm{N}$ ind= number of individuals

\begin{tabular}{|c|c|c|c|c|}
\hline Wing morphism & $\mathrm{N}$ spec & $\%$ spec & $\mathrm{N}$ ind & $\%$ ind \\
\hline \multicolumn{5}{|c|}{ Kettle holes $(\mathrm{N}=8)$} \\
\hline brachypterous & 3 & 2.5 & 80 & 1.1 \\
\hline dimorphic/polymorphic & 29 & 24.2 & 2608 & 35.3 \\
\hline $\begin{array}{l}\text { dimorphic/polymorphic with flight } \\
\text { observations }\end{array}$ & 3 & 2.5 & 439 & 5.9 \\
\hline $\begin{array}{l}\text { monomorphic/ polymorphic } \\
\text { macropterous }\end{array}$ & 12 & 10.0 & 261 & 3.5 \\
\hline macropterous with flight observations & 73 & 60.8 & 3993 & 54.1 \\
\hline \multicolumn{5}{|c|}{ Set aside/ arable field $(\mathrm{N}=2)$} \\
\hline brachypterous & 4 & 7.0 & 733 & 20.6 \\
\hline dimorphic/polymorphic & 18 & 31.6 & 694 & 19.5 \\
\hline $\begin{array}{l}\text { dimorphic/polymorphic with flight } \\
\text { observations }\end{array}$ & 2 & 3.5 & 37 & 1.0 \\
\hline $\begin{array}{l}\text { monomorphic/polymorphic } \\
\text { macropterous }\end{array}$ & 5 & 8.8 & 107 & 3.0 \\
\hline macropterous with flight observations & 28 & 49.1 & 1992 & 55.9 \\
\hline
\end{tabular}

However, nearly $60 \%$ of the species occurring at the reference plots and approximately $70 \%$ from the kettle hole plots exhibit macropterous wing morphologies, and for the predominantly portion, flight observations exist. This indicates that potential migration ability by flight both is very high between the kettle holes and the open land represented by the reference plots.

\section{DISCUSSION}

We found that carabid beetle assemblages are very specific to each of the investigated kettle holes. Even if the kettle holes are very close to each other, which was the case for M27 and M28, the carabid beetle assemblages differ to a considerable extent. In contrast, spider assemblages appear to be relatively consistent between the kettle hole plots. For carabid beetles, Hamel $(1988,1996)$ described the kettle holes as unique "individual" environments within the agrarian landscape. The conditions of individual kettle holes differ considerably in terms of hydrogeomorphological and other abiotic site factors, which may indicate that the differences found in the composition of the carabid beetle assemblages are caused by differences in the environmental variables. From the RDA, we determined that the water volume and the percentage of organic matter of the plot soil are two of the most important 
Platen R., Kalettka T., Ulrichs Ch.: Kettle holes in the agrarian landscape: Isolated and ecological unique habitats for Carabid beetles (Col.: Carabidae) and spiders (Arach.: Araneae)

differentiating factors between the kettle holes. Humidity is cited as being the most important factor for the composition of carabid beetle assemblages, e.g., Hengeveld (1979), Holopainen et al. (1995), and Dijk (1996). Indeed, Hengeveld (1979) attributed the patterns of distribution by some carabid beetle species within a field, including Pterostichus melanarius Illiger and Pterostichus madidus (Fabricius), to the corresponding patterns of soil moisture. The water volume explains $22 \%$ of the variance in the carabid beetle species data. However, the numbers of individuals of hygrophilic species do not match the soil humidity at the kettle hole plots in any case, which may be because the water volume was measured only twice a year, once in August which does not occur within the period of maximal activity of carabid beetles. The extreme poorness of carabid beetle species and individuals that was observed in the peaty like kettle hole M192 was also reported by Barndt (2005) for a kettle hole moor in eastern Brandenburg.

Another factor that explains $6 \%$ of the variance along the $2^{\text {nd }}$ axis of the ordination diagram is the $\mathrm{pH}$. Some authors have found that $\mathrm{pH}$ is an important but inconsistent factor between environments. Holopainen et al. (1995) found in their study of 16 arable fields that the $\mathrm{pH}$ is the least important factor separating carabid communities. Baguette (1987) suggested that $\mathrm{pH}$ may exert indirect effects on the degradation and availability of organic material in the soil, which, in turn, might affect prey availability for carabid beetles. However, in laboratory experiments, Paje \& Mossakowski (1984) found that most carabid beetles preferred a $\mathrm{pH}$ consistent with that in their native environment. Concerning the mechanical soil properties, soil structure and particle size are directly related to the water capacity of soils. However, particle size has different impacts on the distribution of carabid assemblages, as seen in Figure 1. The arrows of fine particle sizes point in the direction of the non-kettle hole plots set-aside (Mus05) and barley field (MuA62). The factors of water volume and the percentage of organic matter are apparently more important in organic soils to determine carabid beetle assemblages. Particle size appears to be a great more determining factor in mineral soils and all fractions together explain ca. $20 \%$ of the variance in the species data.

The distribution of the maximal proportions of numbers of individuals for carabid beetles demonstrate that each of the kettle holes have different ecological properties which meet different ecological requirements of the species. Thus, almost each of the kettle holes contains a ecologically different carabid beetle coenosis. In contrast, most of the different requirements of the spiders comply with the ecological characteristics of only three kettle holes. Within a block of four (five) kettle holes the spider assemblages are rather unspecific. In contrast to the carabid beetles, the ecological composition of the spider assemblages better fits with the environmental variables measured in the kettle holes. The RDA results reveal that $15 \%$ of the variance in the spider species data are explained by the coverage of the grass layer which is consistent with the results of Bell et al. (2001) and Rypstra et al. (1999) who found that the vegetation structure was an essential factor in the distribution of spiders in the environment. Dense vegetation fulfils the spiders' requirements for web building and overwintering places. In comparison, water volume was only $9 \%$ of the variance explanation and organic matter was $4 \%$. The directions and lengths of the environmental arrows in Figure 2 are mostly consistent with the abiotic and biotic factors measured at the kettle hole plots.

As many of the found carabid species by us are potentially capable of flying (Table 6), we predict that the carabid beetle fauna are more homogenously spread over the kettle holes than observed. However, Duelli et al. (1990); Joyce et al. (1999); Mader et al. (1990); Thomas \& Marshall (1999); and Thomas et al. (1998, 2002, 2003) could show (using directional pitfall traps placed at the edges of hedgerows and other barriers between fields) that even winged 
carabid beetles migrate between these environments by walking rather than by flying. Matalin $(1994,2003)$ determined the flight ability of 69 carabid beetle species caught in the south-western plain of the river Prut, Moldova Region, on the basis of biometrical data such as wing area and the development of flight muscles. From these measurements, he calculated an index of potential mobility (IPM), which ranges from zero (no potential for flight) and 1.0 (fully capable of flight). Roughly half of the species we caught in both, the kettle holes and the reference plots were macropterous. In comparison with Matalin's data, the IPM of our dimorphic species ranged from 0.002 to 0.53 , from 0.25 to 0.83 in polymorphic macropterous species, and from 0.53 to 1.00 in monomorphic macropterous species (nine out of 10 species of all of the three wing morphological types). Kotze \& O'Hara (2003) stated that dimorphic carabid species may survive better in environments with high dynamics, such as riverbanks than monomorphic macropterous and brachypterous species the former are able to disperse better between suitable habitats whilst the latter are capable to survive within newly colonized habitats. Bonn \& Helling (1997) and Bonn (2000) found a high flight activity at the banks of the Elbe River in spring, when the river was inundated. They concluded that the beetles were in the process of colonizing new emerging habitats as the water level retreated. Boer (1977, 1990); Wallin (1985, 1987a,b) and Desender (1989) found a correlation between dispersal, habitat selection and reproduction in field inhabiting carabid beetles. Dyck and Baguette (2005) differentiate routine (random) from special movement (dispersal) and they stated that dispersal is a by-product of routine movements and predicted that dispersal would be hindered by habitat fragmentation and thus leads to increasingly isolated populations. We assume, that though many of the carabid beetles found in the kettle holes are capable of flight they would rather stay in a suitable environmental than take the risk to immigrate by flight which would require a high cost of energy. Furthermore, the risk is high of starving or being caught by predators on their airborne way. Blem (1980) stressed out that especially for small insects, dispersal by flight is relatively expensive, because the cost of locomotion is an inverse function of the body weight (Tucker, 1970). Tucker (1970) stressed out that locomotion by flight is more effective in dispersal than walking but he did not present an example with direct comparison of the costs of transport of these two modes of dispersal used by the same species. Desender (2000) could show that there is a seasonal pattern of light muscle development. He figured out that in most of the species studied there is a trade-off between dispersal and reproduction (oogenesis-flight syndrome). Ripe ovaries have a negative relation with functional flight musculature and vice versa. Tietze (1963) found a reduction of flight muscles in some morphological macropterous species. Geipel \& Kegel (1989) investigated three extremely isolated roadside strips in Berlin to carabid beetles and found very few $(<4 \%)$ of macropterous individuals with fully developed flight muscles. In contrast, approximately $85 \%$ of the 454 individuals with weekly developed flight muscles had ripe ovaries and testes, respectively and thus were at the peak of their reproduction period. They found no evidence of an "oogenesis-flight syndrome" and concluded that even in highly isolated habitats macropterous or dimorphic carabid beetles chose to reproduce in their isolated habitats rather than prepare to emigrate by flight through the development of their flight muscles.

In contrast to carabid beetles, many spider species disperse by ballooning, e.g., Linyphiidae as adults and as juveniles, and nearly all other families at least as juveniles (Johnson, 1969; Dingle, 1978, 1980; Bonte et al., 2003; Thomas \& Jepson, 1997; Bell et al., 2005). Spiders do not urgently need to compensate the loss of protein because some of them, e.g. Erigone atra Blackwall 1833 may survive hunger for more than a year (Bell et al., 2005). For spiders, the loss of energy may be less than for carabid beetles which need to fill up their energy reserves by external sources, e.g., by hunting prey which means additional energy 
consumption. From 119 species observed in this study, for $48(40.3 \%)$ ballooning data were recorded by Bell et al. (2005), and among those is included many of the most frequently caught, e.g., the species of the genus Oedothorax and most of the wolf spider species. However, it is unclear whether these species actually are moving frequently between the kettle holes by ballooning.

We conclude that both, the specific environmental properties in each of the kettle holes and the different modes of migration, lead to the different composition of carabid beetle and spider assemblages in the kettle holes. The carabid beetle assemblages are more specific for each of the kettle holes, whereas the spider assemblages are more similar between the kettle holes. Further studies may reveal whether the carabid beetle and spider populations primarily reproduce within the kettle holes, where they spend much of their lives, and how much migration activity occurs between different kettle holes and adjacent wetland populations. Genetic studies are necessary to determine the amount of gene flow between the populations, and to address the question of how much isolation each type of population experiences.

\section{ACKNOWLEDGEMENTS}

We like to thank Sigrid Ehlert for GIS-mapping, Melitta Engel, Dorith Henning and Rita Schwarz for assistance in the laboratory, and Dorett Berger for literature research. Special thanks to Karl-Hinrich Kielhorn for revising an earlier version of this manuscript.

\section{REFERENCES}

Anderßon, A. \& Anderßon, O., (2015, January). Andersson-Info, Web-App Biostatistik. Retrieved January 31, 2015, from http://www.andersson-info.de/bio.php.

Baguette, M., (1987) Spring distribution of carabid beetles in different plant communities of Belgian forests. Acta Phytopathologica Entomologica Hungarica, 22, (1-4) 57-69.

Barber, H.S., (1931). Traps for cave inhabiting insects. J. Elisha Mitchell Sci. Soc., 46 (2), 259-266.

Barndt, D., Brase, S., Glauche, M., Gruttke, H., Kegel, B., Platen, R., Winkelmann, H., (1991). Die Laufkäferfauna von Berlin (West)-mit Kennzeichnung und Auswertung der verschollenen und gefährdeten Arten (Rote Liste, 3. Fassung). In Auhagen, A., Platen, R. \& Sukopp, H. Rote Liste der gefährdeten Pflanzen und Tiere in Berlin (pp. 243-275). Landschaftsentwicklung und Umweltforschung. Special Issue 6, Berlin: Technische Universität.

Barndt, D., (2005). Beitrag zur Arthropodenfauna des Naturparks Schlaubetal und Umgebung - Faunenanalyse und Bewertung (Coleoptera, Heroptera, Saltatoria, Araneae, Opiliones, u.a.). Märkische Entomologische Nachrichten, 7 (2), 45-102.

Bell, J.R., Wheater, C.P. \& Cullen, W.R., (2001). The implications of grassland and heathland management for the conservation of spider communities: a review. J. Zool., 255 (3), 377-387. DOI: 10.1017/S0952836901001479.

Bell, J.R., Bohan, D.A., Shaw, E.M. \& Weyman, G.S., (2005). Ballooning dispersal using silk: world fauna, phylogenies, genetics and models. B. Entomol. Res., 95 (2), 69-114. DOI: 10.1079/BER2004350.

Berger, G., Pfeffer, H. \& Kalettka, T,. (2010). Amphibienschutz in kleingewässerreichen Ackerbaugebieten. Rangsdorf: Natur \& Text. 
Blem, C. R., (1980). The energetics of migration. In S.A.Gauthreaux (Ed.), Aninmal Migration, Orientation and Navigation (pp. 175-223). New York: Academic Press. DOI: 10.1016/B978-0-08-091833-4.50008-0.

Boer, P.J. den, (1977). Dispersal power and survival. carabids in a cultivated countryside. Miscellaneous Papers. Landbouwhogeschool Wageningen, 14, 1-190.

Boer, P.J. den,(1990). Density limits and survival of local populations in 64 carabid species with different powers of dispersal. J. Evolution. Biol., 3 (1-2), 19-48. DOI: 10.1046/j.1420-9101.1990.3010019.x.

Boix, D., Biggs, J., Céréghino, R., Hull, A. P., Kalettka, T. \& Oertli, B., (2012). Pond research and management in Europe: "Small is Beautiful". Hydrobiologia, 689 (1), 1-9. DOI: $10.1007 / \mathrm{s} 10750-012-1015-2$.

Bonn, A., (2000). Flight activity of carabid beetles on a river margin in relation to fluctuating water levels. In Brandmayr, P., Lövei, G., Zetto Brandmayr, T., Cascale, A. \& Vigna Taglianti, A. (Eds.), Natural history and applied ecology of carabid beetles (pp. 147-160). Sofia,Moscow: Pensoft Publishers.

Bonn, A. \& Helling, B., (1997). Einfluß von schwankenden Wasserständen auf die Flugaktivität von Laufkäfern. Mitt.DGaaE, 11, 439-442.

Bonte, D., Vandenbroeke, N., Lens, L. \& Maelfait, J.P., (2003). Low propensity for aerial dispersal in specialist spiders from fragmented landscapes. P. Roy. Soc. Lond. B Bio., 270 (1524), 1601-1607. DOI: 10.1098/rspb.2003.2432.

Bosiacka, B. \& Piénkowski, P., (2012). Do biogeographic parameters matter? Plant species richness and distribution of macrophytes in relation to area and isolation of ponds in NW Polish agricultural landscape. Hydrobiologia, 689 (1), 79-90. DOI: 10.1007/s10750011-0850-x.

Braak, C. J. F. ter \& Smilauer, P., (2002). CANOCO Reference Manual and CanoDraw for Windows User's Guide. Software for Canonical Community Ordination [Computer Software]. Wageningen, České Budějovice: Biometris.

Brose, U., (2001). Artendiversität der Pflanzen- und Laufkäfergemeinschaften (Coleoptera, Carabidae) von Nassstellen auf mehreren räumlichen Skalenebenen. Dissertationes Botanicae, 345, Stuttgart: J. Cramer Verlag.

Brose, U., (2003a). Regional differences of temporary wetland carabid beetle communities: a matter of landscape features or cultivation intensity? Agr. Ecosys.Environ., 98 (1-3), 163-167. DOI: 10.1016/S0167-8809(03)00078-1.

Brose, U., (2003b). Island biogeography of temporary wetland carabid beetle wetland communities. J. Biogeogr., 30 (6), 879-888. DOI: 10.1046/j.1365-2699.2003.00893.x.

De Meester, L., Declerck, S., Stoks, R., Louette, G., Van de Meutter, F., De Bie, T., Michels, E. \& Brendonck, L., (2005). Ponds and pools as model systems in conservation biology, ecology and evolutionary biology. Aquat. Conserv., 15 (6), 715-725. DOI: 10.1002/aqc.748.

Desender, K., (1989). Dispersievermoegen en ecologie van loopkevers (Coleoptera, Carabidae) in Belgie: een evolutionaire benadering. Documents de Travail de l'Institut Royale des Sciences naturelles de Belge, Gent, 54, 1-136.

Desender, K., (2000). Flight muscle development and dispersal in the life cycle of carabid beetles: patterns and processes. Bulletin de l'Institut Royal des Sciences Naturelles de Belgique, Entomologie, 70, 13-31.

Dierschke, H., (1994). Pflanzensoziologie: Grundlagen und Methoden. Stuttgart : Ulmer.

Dijk, T.S. van, (1996). The influence of environmental factors and food on life cycle ageing 
and survival of some carabid beetles. Acta Jutlandica, 71 (2), 11-24.

Dingle, H., (Ed.) (1978). Evolution of Insect Migration and Diapause. New York: Springer. Dingle, H., (1980). Ecology and evolution of migration. In S.A. Gauthreaux (Ed.), Animal Migration, Orientation, and Navagation. (pp. 1-101). New York : Academic Press. DOI: 10.1016/B978-0-08-091833-4.50006-7.

Duelli, P., Studer, M., Marchand, I. \& Jakob, S., (1990). Population movements of arthropods between natural and cultivated areas. Biol. Conserv., 54 (3), 193-207. 10.1016/0006-3207(90)90051-P.

Dyck, H. van \& Baguette, M., (2005). Dispersal behaviour in fragmented landscapes: Routine or special movements? Basic and Applied Ecology, 6 (6), 535-545. DOI: 10.1016/j.baae.2005.03.005.

Euliss N. H. Jr., Smith, L. M., Wilcox, D. A. \& Brwaine, B. A., (2008). Linking ecosystem processes with wetland management goals: Charting a course for a sustainable future. Wetlands, 28 (3), 553-562. DOI: 10.1672/07-154.1.

Frielinghaus, M., (1996). Extensivierung der Landnutzung und Vertragsnaturschutz im Einzugsgebiet von Söllen, dargestellt am Beispiel der Söllekette Lietzen/Döbberin. Natursch. Landschaftspfl. Brandenburg, 5, Special Issue „Sölle“, 18-21.

GAC (Gesellschaft für angewandte Carabidologie), (Eds.) (2009). Lebensraumpräferenzen der Laufkäfer Deutschlands - Wissensbasierter Katalog. Angewandte Carabidologie, Supplement V, 1-45.

Geipel, K.-H. \& Kegel, B., (1989). Die Ausbildung der metathoracalen Flugmuskulatur von Laufkäferpopulationen ausgewählter Straßenrandbiotope in Berlin (West). Verh. Ges. Ökologie, 17, 727-732.

Gerke, H., Koszinski, S., Kalettka, T. \& Sommer, M., (2010). Structures and hydrologic function of soil landscapes with kettle holes using an integrated hydropedological appproach. J. Hydrol. 393 (1-2), 123-132. DOI: 10.1016/j.jhydrol.2009.12.047.

Gleason, R.A., Euliss, N.H., Tangen, B.A., Laubhan, M.K. \& Browne, B.A., (2011). USDA conservation program and practice effects on wetland ecosystem services in the Prairie Pothole Region. Ecol. Appl. 21 (3), 65-81. DOI: 10.1890/09-0216.1.

Greulich, K. \& Schneeweiss, N., (1996). Hydrochemische Untersuchungen an sanierten Kleingewässern einer Agrarlandschaft (Barnim, Brandenburg) unter besonderer Berücksichtigung der Amphibienfauna. Natursch. Landschaftspfl. Brandenburg, 5, Special Issue ,Sölle“, 22-30.

Haacke, H., Henze, R. \& Kohl, J.-G., (1996). Limnologische Untersuchungen an ausgewählten Söllen. Natursch. Landschaftspfl. Brandenburg, 5, Special Issue „Sölle“, 44-48.

Hamel, G., (1988). Nutzungsgeschichte, Sukzession und Habitatfunktion von Kleingewässern in der Agrarlandschaft. Naturschutzarbeit in Berlin und Brandenburg, 24, 67-79.

Hamel, G., (1996). Zum Geleit. Natursch. Landschaftspfl. Brandenburg, 5, Special Issue „Sölle“:3.

Heimer, S. \& Nentwig, W., (1991). Spinnen Mitteleuropas. Ein Bestimmungsbuch. Hamburg, Berlin: Paul Parey.

Hengeveld, R., (1979). The analysis of spatial patterns of some ground beetles (Col.: Carabidae). In Cormack, R.M. \& Ord, J.K. (Eds.), Spatial and temporal analysis in ecology 
(pp. 333-346). Fairland: International Co-operative Publishing house.

Holopainen, J.K., Bergman, T., Hautala, E.L. \& Oksanen, J., (1995). The ground beetle fauna (Coleoptera: Carabidae) in relation to soil properties and foliar fluoride content in spring cereals. Pedobiologia, 39 (3), 193-206.

Johnson, G., (1969). Migration and Dispersal of Insects by Flight. London: Methuen.

Joyce, K.A., Holland, J.M. \& Doncaster, C.P., (1999). Influences of hedgerow intersections and gaps on the movement of carabid beetles. B. Entomol. Res., 89 (6), 523-531. DOI: 10.1017/S000748539900067X.

Kalettka, T., (1996). Die Problematik der Sölle (Kleinhohlformen) im Jungmoränengebiet Nordostdeutschlands. Natursch. Landschaftspfl. Brandenburg, 5, Special Issue „Sölle“, 4-12.

Kalettka, T., Rudat , C. \& Quast, J., (2001). "Potholes"' in Northeast German agro-landscapes: functions, land use impacts, and protection strategies. In Tenhunen, J. D., Lenz, R. \& Hantschel, R. (Eds.), Ecosystem Approaches to Landscape Management in Central Europe. Ecological Studies, 147 (pp. 291-298), Berlin, Heidelberg: Springer.

Kalettka, T. \& Rudat, C., (2006). Hydrogeomorphic types of glacially created kettle holes in North-East Germany. Limnologica, 36 (1), 54-64. DOI: 1016/j.limno.2005.11.001.

Kleeberg, A. \& Schmidt, J., (1999). Laufkäfer- und Kurzflügelkäferfunde in der Sölle-Kette Lietzen-Döbberin (Ost-Brandenburg) (Coleoptera: Carabidae, Staphylinidae). Märkische Entomologische Nachrichten, 1 (1), 49-54.

Kleeberg, A., Neyen, M. \& Kalettka, T., (2015). Element-specific downward fluxes impact the metabolism and vegetation of kettle holes. Hydrobiologia 766 (1), 261-274. DOI 10.1007/s10750-015-2460-5.

Köhler F. \& Klausnitzer B., (Eds.) (2015, February). Entomofauna Germanica. Retrieved April 30, 2015, from http://www.coleokat.de/de/fhl/.

Kotze, D. J. \& O'hara, R. B., (2003). Species decline-but why? Explanations of carabid beetle (Coleoptera, Carabidae) declines in Europe. Oecologia, 135 (1), 138-148. DOI: 10.1007/s00442-002-1174-3.

Larsson, S.G., (1939). Entwicklungstypen und Entwicklungszeiten der Dänischen carabiden. Entomologiske Meddeleser, 10, 277-560+Appendix

Legendre, P. \& Gallagher, E.D., (2001). Ecologically meaningful transformations for ordination of species data. Oecologia, 139 (2), 271-280. DOI: 10.1007/s004420100716.

Lindroth, C.H., (1992a). Ground beetles (Carabidae) of Fennoscandia. A Zoogeogrphic Study. Pt. II. General Analysis. Andover : Intercept.

Lindroth, C.H., (1992b). Ground beetles (Carabidae) of Fennoscandia. A Zoogeogrphic Study. Pt. III. Andover, Intercept.

Lischeid, G. \& Kalettka, T., (2012). Grasping the heterogeneity of kettle hole water quality in Northeast Germany. Hydrobiologia, 689 (1), 63-77. DOI: 10.1007/s10750-011-0764-7.

Luthardt, V. \& Dreger, F., (1996). Ist-Zustands-Analyse und Bewertung der Vegetation von Söllen in der Uckermark. Natursch. Landschaftspfl.Brandenburg, 5, Special Issue „Sölle“, 31-38.

Mader, H.J., Schell, C. \& Kornacker, P. (1990). Linear barriers to arthropod movement in the landscape. Biol. Conserv., 54 (3), 209-222. DOI: 10.1016/0006-3207(90)90052-Q.

Matalin, A.V., (1994). The strategy of dispersal behaviour in some Carabidae species of Southeastern Europe. In Desender, K., Loreau, M., Luff, M.L. \& Maelfait, J.P. (Eds.), 
Platen R., Kalettka T., Ulrichs Ch.: Kettle holes in the agrarian landscape: Isolated and ecological unique habitats for Carabid beetles (Col.: Carabidae) and spiders (Arach.: Araneae)

Carabid beetles. Ecology and Evolution (pp. 183-188). Dodrecht: Kluwer Academic Publishers. DOI: 10.1007/978-94-017-0968-2_28.

Matalin, A.V., (2003). Variations in flight ability with sex and age in ground beetles (Coleoptera, Carabidae) of south-western Moldova. Pedobiologia, 47 (4), 311-319. DOI: 10.1078/0031-4056-00195.

Mühlenberg, M., (1993). Freilandökologie (3rd ed). Heidelberg, Wiesbaden: Quelle \& Meyer.

Müller-Motzfeld, G., (2004). Adephaga 1, Carabidae (Laufkäfer). Die Käfer Mitteleuropas. Volume 2 (2nd ed). Heidelberg, Berlin: Spektrum Verlag.

Niedringhaus, R. \& Zander, B., (1998). Die Kleingewässer der ostfriesischen Inseln Zustandsanalyse und ökologische Bewertung anhand der Flora/Vegetation und Wirbellosenfauna. Schriften-Reihe Nationalpark Niedersächsisches Wattenmeer, 3, 1-270.

Pätzig, M., Kalettka, T., Glemnitz, M. \& Berger, G., (2012). What governs macrophyte species richness in kettle hole types? A case study from Northeast Germany. Limnologica, 42 (4), 340-354. DOI: 10.1016/j.limno.2012.07.004.

Paje , F. \& Mossakowski, D., (1984). PH-preferences and habitat selection in carabid beetles. Oecologia, 64 (1), 41-46. DOI: 10.1007/BF00377541.

Pienkowski, P., (2000). Disappearance of ponds in the younger pleistocene landscapes of Pomerania. J. Water Land Dev., 4, 55-68.

Platen, R., Moritz, M. \& Broen, B. von, (1991). Liste der Webspinnen- und Weberknechtarten (Arach.: Araneida, Opilionida) des Berliner Raumes und ihre Auswertung für Naturschutzzwecke (Rote Liste). In Auhagen, A., Platen, R. \& Sukopp, H. (Eds.), Rote Liste der gefährdeten Pflanzen und Tiere in Berlin (pp. 169-205). Landschaftsentwicklung und Umweltforschung. Special Issue, 6, Berlin: Technische Universität.

Platen, R., Broen, B. V., Hermann, A., Ratschker, U.M. \& Sacher, P., (1999). Gesamtartenliste und Rote Liste der Webspinnen, Weberknechte und Pseudoskorpione des Landes Brandenburg (Arachnida: Araneae, Opiliones, Pseudoscorpiones) mit Angaben zur Häufigkeit und Ökologie. Natursch. Landschaftspfl. Brandenburg, 8. Supplement.

Platnick, N., (2013). The World Spider Catalog, Version 13.5. New York: American Museum of Natural History. Retrieved January 2015, from https://research.amnh.org /iz/spiders/catalog_13.5/INTRO1.html.

Roberts, M.J., (1985). The spider fauna of Great Britain and Ireland. Atypidae-Theridiosomatidae. Colchester: Brill Archive.

Roberts, M.J., (1987). The spider fauna of Great Britain and Ireland. Linyphiidae. Colchester: Brill Archive.

Roberts, M.J., (1995). Spiders of Britain \& Northern Europe. London: HarperCollins Publishers.

Rypstra, A.L., Carter, P.E., Balfour, R.A. \& Marshall, S.D., (1999). Architectural features of agricultural habitats and their impact on the spider inhabitants. J. Arachnol., 27 (1), 371-377.

Scheffer, M., Van Geest, G.J., Zimmer, K., Jeppesen, E., Søndergaard, M., Butler, M. G., Hanson, M. A., Declerck, S. \& De Meester, L., (2006). Small habitat size and isolation can promote species richness: second-order effects on biodiversity in shallow lakes and ponds. Oikos 112 (1), 227-231. DOI: 10.1111/j.0030-1299.2006.14145.x.

Schindler, U., (1996). Untersuchungen zum Wasserhaushalt kleiner Binneneinzugsgebiete mit Söllen im Nordostdeutschen Jungmoränengebiet am Beispiel des „Breiten Fenn“. 
Natursch. Landschaftspfl. Brandenburg, 5, Special Issue „Sölle“, 39-43.

Schlichting, E., Blume, H. P. \& Stahr, K., (1995). Bodenkundliches Praktikum (2nd ed.). Berlin: Blackwell.

Schmidt, J., (2005). Plädoyer für die Behutsamkeit bei Kleingewässersanierungen Ergebnisse einer Erfassung von Laufkäfern in Ackerhohlformen. Naturschutzarbeit in Mecklenburg-Vorpommern, 48 (1), 44-54.

Schneeweiss, N., (1996). Habitatfunktion von Kleingewässern in der Agrarlandschaft am Beispiel der Amphibien. Natursch. Landschaftspfl. Brandenburg, 5, Special Issue „Sölle“, 13-17.

Sokal, R.R. \& Rohlf, F.J., (2012). Biometry: The principles and practice of statistics in biological research ( $4^{\text {th }}$ ed.). New York: WH Freeman and Co.

Thomas, C.F.G. \& Jepson, P.C., (1997). Field-scale effects of farming practices on linyphiid spider populations in grass and cereals. Entomol. Exp. Appl., 84 (1), 59-69. DOI: 10.1046/j.1570-7458.1997.00198.x.

Thomas, C.F.G. \& Marshall, E.J.P., (1999). Arthropod abundance and diversity in differently vegetated margins of arable fields. Agr. Ecosyst. Environ., 72 (2), 131-144. DOI: 10.1016/S0167-8809(98)00169-8.

Thomas, C.F.G., Parkinson, L. \& Marshall, E.J.P., (1998). Isolating the components of activity-density for the carabid beetle Pterostichus melanarius in farmland. Oecologia, 116 1), 103-112. DOI: 10.1007/s004420050568.

Thomas, C.F.G., Holland, J.M. \& Brown, N.J., (2002). The spatial distribution of carabid beetles in agricultural landscapes. In Holland, J.M. (Ed.), The Agroecology of Carabid beetles (pp. 305-344). Andover: Intercept.

Thomas, C.F.G., Brain, P. \& Jepson, P.C., (2003). Aerial activity of linyphiid spiders: modelling dispersal distances from meteorology and behaviour. J. Appl. Ecol., 40 (5), 912-927. DOI: 10.1046/j.1365-2664.2003.00844.x.

Tietze, F., (1963). Untersuchungen über die Beziehungen zwischen Flügelreduktion und Ausbildung des Metathorax bei Carabiden unter besonderer Berücksichtigung der Flugmuskulatur (Coleoptera, Carabidae). Beiträge zur Entomologie, 13 (1-2), 87-163.

Tucker, V.A., (1970). Energetic cost of locomotion in animals. Comp. Biochem. Physiol., 34 (4), 841-846. DOI: 10.1016/0010-406X(70)91006-6.

Waldon, B., (2012). Natural value and endangerment of small water reservoirs in the Krajeńskie Lakeland (North-West Poland). Limnologica, 42 (4), 320-327. DOI: 10.1016/j.limno.2012.07.006.

Wallin, H., (1985). Spatial and temporal distribution of some abundant carabid beetles (Coleoptera: carabidae) in cereal fields and adjacent habitats. Pedobiologia, 28 (1), 19-34.

Wallin, H., (1987a). Dispersal and migration of carabid beetles inhabiting cereal fields. Acta Phytopathol. Hun., 22 (1-4), 449-453.

Wallin, H., (1987b). Habitat selection, reproduction and survival of Bembidion lampros Herbst and Trechus secalis Paykull (Coleoptera: Carabidae) on arable land. Plant Protection Reports and Documentations of the Swedish University for Agricultural Sciences, 19, 1-25.

Wiehle, H., (1956). Linyphiidae-Baldachinspinnen. Die Tierwelt Deutschlands und angrenzender Meeresteile. Vol. 44. Jena: Gustav Fischer.

Wiehle, H., (1960). Micryphantidae-Zwergspinnen. Die Tierwelt Deutschlands und angrenzender Meeresteile Vol. 47. Jena: Gustav Fischer 


\section{APPENDIX}

Table A1: The environmental variables determined at the plots investigated. All of the units are presented as percent except where otherwise indicated and for the $\mathrm{pH}$.

PercOrg $=$ Percentage of organic matter, $\mathrm{WV}=$ Water volume, $\mathrm{CoSa}=$ Coarse sand, MeSa $=$ Medium sand, FiSa $=$ Fine sand, CovHerb $=\mathrm{Cover}$ Herb layer, CovGrass $=$ Cover Grass layer . n.v.=no value available.

\begin{tabular}{|c|c|c|c|c|c|c|c|c|c|c|c|c|c|c|}
\hline \multirow[t]{2}{*}{ Plots } & \multicolumn{5}{|c|}{ Hydrogeomorphology } & \multicolumn{7}{|c|}{ Soil } & \multicolumn{2}{|c|}{ Vegetation } \\
\hline & $\begin{array}{c}\text { Catchment } \\
\text { Area }\end{array}$ & $\begin{array}{c}\text { Kettle } \\
\text { hole } \\
\text { Area } \\
\end{array}$ & Shore Slope & Hydroperiod & $\begin{array}{l}\text { Max. } \\
\text { depth }\end{array}$ & $\mathrm{pH}$ & PercOrg & WV & $\mathrm{CoSa}$ & $\mathrm{MeSa}$ & FiSa & Silt & CovHerb & CovGrass \\
\hline & [ha] & [ha] & [\%] & & {$[\mathrm{m}]$} & & {$[\%]$} & {$[\%]$} & {$[\%]$} & {$[\%]$} & {$[\%]$} & {$[\%]$} & {$[\%]$} & {$[\%]$} \\
\hline M9 & 10.02 & 0.22 & 15.8 & episodic & 1.02 & 6.2 & 26.0 & 32.6 & 29.0 & 36.4 & 25.6 & 9.0 & 18.8 & 66.8 \\
\hline M19 & 2.22 & 0.10 & 23.2 & semipermanent & 1.66 & 5.3 & 21.2 & 67.1 & 19.8 & 39.2 & 28.8 & 12.2 & 35.5 & 62.5 \\
\hline M27 & 11.05 & 1.05 & 28.6 & semipermanent & 4.24 & 4.9 & 26.0 & 66.7 & 19.6 & 28.4 & 35.3 & 16.8 & 76.1 & 22.4 \\
\hline M28 & 1.06 & 0.09 & 22.7 & periodic & 1.80 & 4.2 & 18.8 & 44.4 & 18.1 & 30.1 & 24.3 & 24.9 & 13.5 & 79.1 \\
\hline M38 & 1.40 & 0.4 & 19.5 & periodic & 1.91 & 4.5 & 42.0 & 86.0 & 39.1 & 37.9 & 27.4 & 13.0 & 13.8 & 90.0 \\
\hline M46 & n.v. & n.v. & 26.2 & episodic & 1.14 & 4.1 & 13.5 & 39.0 & 23.1 & 51.3 & 39.1 & 37.0 & 6.1 & 90.5 \\
\hline M53 & n.v. & n.v. & n.v. & n.v. & n.v. & 6.2 & 23.2 & 56.3 & 15.9 & 36.0 & 32.3 & 12.1 & 30.8 & 87.9 \\
\hline M192 & 4.82 & 2.00 & 25.4 & permanent & 1.37 & 3.4 & 77.2 & 86.6 & 15.7 & 27.0 & 20.9 & 36.4 & 8.7 & 1.6 \\
\hline MuS05 & - & & - & - & - & 5.1 & 11.2 & 12.2 & 13.8 & 37.4 & 31.6 & 17.2 & 65.4 & 23.4 \\
\hline MuA62 & - & & - & - & - & 6.0 & 3.6 & 12.9 & 9.9 & 38.8 & 37.2 & 14.0 & 0.0 & 68.8 \\
\hline
\end{tabular}


Table A2: A list of carabid beetle species including the short cuts used in Fig. 1, the total number of individuals caught in the trapping period and details on biology, ecological and functional groups.

$\mathrm{EG}=$ ecological group: $\mathrm{h}=$ hygrophilic, $(\mathrm{h})=$ moderately hygrophilic, $\mathrm{x}=$ xerophilic, $(\mathrm{x})=$ moderately xerophilic, eu= eurytopic, $\mathrm{hf}=\mathrm{hygrophilic}$ in forests, $\mathrm{h}(\mathrm{f})=$ hygrophilic in open sites and forests, $(\mathrm{h}) \mathrm{f}=$ moderately hygrophilic and in forests, $(\mathrm{h})(\mathrm{f})=$ moderately hygrophilic and predominantly in forests, $(\mathrm{x}) \mathrm{f}=$ moderately xerophilic and in forests, $(\mathrm{x})(\mathrm{f})=$ moderately xerophilic and predominantly in forests; $\mathrm{HP}=$ habitat preference: af $=$ arable fields; fa $=$ fallows ; wet, open habitats $($ as summarized in Fig. 2): ba= banks, mo= moors, re= reeds; meadows and pastures (as summarized in Fig. 2): wm= wet meadows, pa= pastures; dry, open habitats (as summarized in Fig. 2): $\mathrm{dg}=$ dry grassland; forests (as summarized in Fig. 2): $\mathrm{wf}=$ wet forests, $\mathrm{mf}=$ moist forests, $\mathrm{mdf}=$ moderately dry forests; $\mathrm{WM}=$ wing morphs: $\mathrm{br}=$ brachypterous, $\mathrm{di}=$ dimorphic, $\mathrm{di}^{*}=$ dimorphic with flight observations, $\mathrm{ma}=$ macropterous, ma*= macropterous with flight observations, $\mathrm{HM}=\mathrm{hibernation}$ mode: $\mathrm{Spr}=$ spring breeders, $(\mathrm{Spr})=$ predominantly spring breeders, Aut $=$ autumn breeders, $(\mathrm{Aut})=$ predominantly autumn breeders, Irr $=\mathrm{Irregular}$ hibernation mode, $\mathrm{BMC}=$ body mass class: $\mathrm{I}=<5 \mathrm{mg}$, II $=5-9.9 \mathrm{mg}$, III= 10-29.9 mg, IV=30-100 mg; V=>100 mg. For the abbreviations for the plots: see Chapter 2.1 .

\begin{tabular}{|c|c|c|c|c|c|c|c|c|c|c|c|c|c|c|c|c|}
\hline Species & Short cut & M9 & M19 & M27 & M28 & M38 & M46 & M53 & M192 & MuS05 & MuA62 & EG & HP & $\mathbf{W M}$ & HM & BMC \\
\hline Abax parallelepipedus & Aba para & & & & & & & & & 1 & & (h) $\mathrm{f}$ & $\mathrm{mf}$ & br & Irr & IV \\
\hline Acupalpus exiguus & Acu exig & 5 & 3 & 2 & 18 & 1 & & 11 & & & & $\mathrm{~h}$ & wm & $\mathrm{ma}^{*}$ & Spr & I \\
\hline Acupalpus flavicollis & Acu flav & & & 3 & 1 & 1 & 1 & & & & & $\mathrm{~h}$ & re & ma* & Spr & I \\
\hline Acupalpus parvulus & Acu parv & & 7 & 3 & 10 & & 1 & 13 & & & & $\mathrm{~h}$ & re & ma* & Spr & I \\
\hline Agonum emarginatum & Ago emar & 22 & 2 & & & & & 1 & & & & $\mathrm{~h}$ & re & di & Spr & II \\
\hline Agonum fuliginosum & Ago fuli & 2 & & & 1 & & & & & & & $h(f)$ & wf & di & (Spr) & I \\
\hline Agonum lugens & Ago luge & 62 & 18 & 26 & 28 & 1 & & 19 & & & & $h(f)$ & re & $\mathrm{ma}^{*}$ & (Spr) & II \\
\hline Agonum marginatum & Ago marg & & & 1 & & & 1 & & & & & $\mathrm{~h}$ & $\mathrm{ba}$ & $\mathrm{ma}^{*}$ & Spr & III \\
\hline Agonum sexpunctatum & Ago sexp & 3 & & & 1 & & & & & & & (h) & wm & $\mathrm{ma}$ & Spr & II \\
\hline Agonum thoreyi & Ago thor & 23 & 4 & 8 & 10 & 3 & & 19 & 3 & 1 & & $\mathrm{~h}$ & re & $\mathrm{ma}^{*}$ & (Spr) & II \\
\hline Agonum viduum & Ago vidu & 35 & 18 & 5 & 4 & 6 & & 10 & & & & $\mathrm{~h}$ & re & $\mathrm{ma}^{*}$ & Spr & II \\
\hline Amara aenea & Ama aene & 5 & 8 & 55 & 28 & 123 & 72 & 15 & 1 & 344 & 11 & (x) & $\mathrm{dg}$ & $\mathrm{ma}^{*}$ & Spr & II \\
\hline Amara apricaria & Ama apri & & 1 & & & 19 & 1 & & & 1 & & (x) & af & $\mathrm{ma}^{*}$ & (Aut) & II \\
\hline Amara aulica & Ama auli & & 1 & & & & & & & & & (x) & $\mathrm{fa}$ & $\mathrm{ma}^{*}$ & Aut & III \\
\hline Amara bifrons & Ama bifr & & 1 & & 1 & & 3 & & & & & $\mathrm{x}$ & $\mathrm{fa}$ & $\mathrm{ma}^{*}$ & Aut & I \\
\hline Amara communis & Ama comm & & & & & 1 & 9 & & & 23 & 1 & (h)(f) & pa & $\mathrm{ma}^{*}$ & (Spr) & II \\
\hline Amara consularis & Ama cons & & & & & & 2 & & & & & $(\mathrm{x})$ & af & ma* & (Aut) & II \\
\hline
\end{tabular}




\begin{tabular}{|c|c|c|c|c|c|c|c|c|c|c|c|c|c|c|c|c|}
\hline Species & Short cut & M9 & M19 & M27 & M28 & M38 & M46 & M53 & M192 & MuS05 & MuA62 & EG & HP & WM & HM & BMC \\
\hline Amara equestris & Ama eque & & & & & & & & & 3 & & $\mathrm{x}$ & $\mathrm{dg}$ & $\mathrm{ma}$ & Aut & III \\
\hline Amara eurynota & Ama eury & & & & & 2 & 1 & & & & & $\mathrm{x}$ & fa & $\mathrm{ma}^{*}$ & Spr & III \\
\hline Amara familiaris & Ama fami & & & 2 & 1 & & & & & 7 & & $(\mathrm{x})(\mathrm{f})$ & af & $\mathrm{ma}^{*}$ & Spr & I \\
\hline Amara lunicollis & Ama luni & & & 2 & 8 & & 40 & & & 54 & 16 & (h) & pa & $\mathrm{ma}^{*}$ & Spr & II \\
\hline Amara ovata & Ama ovat & & & & & & 1 & & 1 & & & (h) & $\mathrm{fa}$ & $\mathrm{ma}^{*}$ & (Spr) & II \\
\hline Amara similata & Ama simi & 2 & 1 & & 6 & 67 & 10 & 2 & & 1 & & $\mathrm{eu}$ & af & $\mathrm{ma}^{*}$ & Spr & II \\
\hline Amara spreta & Ama spre & & & & & 1 & & & & 4 & & $\mathrm{x}$ & af & $\mathrm{ma}^{*}$ & Spr & II \\
\hline Amara tibialis & Ama tibi & & & & & & 1 & & & 9 & 2 & $\mathrm{x}$ & $\mathrm{dg}$ & $\mathrm{ma}^{*}$ & Spr & I \\
\hline Anchomenus dorsalis & Anc dors & & & & 1 & & & 1 & & & 5 & $(\mathrm{x})$ & af & $\mathrm{ma}^{*}$ & Spr & I \\
\hline Anisodactylus binotatus & Ani bino & 25 & 9 & 85 & 11 & 18 & 79 & 5 & & 4 & 1 & $(h)(f)$ & wm & $\mathrm{ma}^{*}$ & Spr & III \\
\hline Anthracus consputus & Ant cons & & 2 & 2 & 1 & & & 5 & & & & $\mathrm{~h}$ & re & $\mathrm{ma}^{*}$ & Spr & $\mathrm{I}$ \\
\hline Asaphidion flavipes & Asa flav & & & & & & & & & & 1 & $\mathrm{eu}$ & af & $\mathrm{ma}^{*}$ & Spr & I \\
\hline Badister bullatus & Bad bull & 9 & & & 1 & & 2 & 1 & & & & $(\mathrm{x})(\mathrm{f})$ & mdf & $\mathrm{ma}^{*}$ & Spr & I \\
\hline Badister dilatatatus & Bad dila & & & & & & & 1 & & & & $\mathrm{~h}$ & mo & $\mathrm{ma}^{*}$ & Spr & I \\
\hline Badister dorsiger & Bad dors & & & & 1 & & & & & & & $\mathrm{~h}$ & re & di & Spr & I \\
\hline Badister peltatus & Bad pelt & & & & & & & 1 & & & & $\mathrm{~h}$ & re & $\mathrm{ma}^{*}$ & Spr & I \\
\hline Badister sodalis & Bad soda & 2 & & 1 & 8 & & & 5 & & & & $h(f)$ & wf & br & Spr & $\mathrm{I}$ \\
\hline Badister unipustulatus & Bad unip & 2 & & & 5 & & & 10 & & & & $h(f)$ & re & $\mathrm{ma}^{*}$ & Spr & II \\
\hline Bembidion articulatum & Bem arti & 1 & & 1 & & & & 2 & & & 1 & $\mathrm{~h}$ & re & $\mathrm{ma}^{*}$ & Spr & I \\
\hline Bembidion doris & Bem dori & 2 & 1 & 4 & 2 & 1 & 2 & 5 & & & & $\mathrm{~h}$ & re & $\mathrm{ma}^{*}$ & Spr & I \\
\hline Bembidion femoratum & Bem femo & & & & & & & & 1 & & & $\mathrm{eu}$ & af & $\mathrm{di} *$ & (Spr) & $\mathrm{I}$ \\
\hline Bembidion gilvipes & Bem gilv & 7 & 2 & & 4 & & 16 & & & 2 & & $\mathrm{~h}$ & wm & di & Spr & I \\
\hline Bembidion guttula & Bem gutt & 40 & 17 & 2 & 3 & 7 & 10 & 41 & & 5 & & $\mathrm{~h}$ & re & di & Spr & I \\
\hline Bembidion lampros & Bem lamp & 1 & & & & 6 & 4 & & & 17 & 42 & $(\mathrm{x})(\mathrm{f})$ & af & di & Spr & I \\
\hline Bembidion lunulatum & Bem lunu & & & & & & 3 & & & & & $\mathrm{~h}$ & wm & $\mathrm{ma}^{*}$ & Spr & I \\
\hline Bembidion mannerheimi & Bem mann & 27 & 4 & 1 & 6 & 2 & 40 & 3 & 1 & 10 & 68 & $h(f)$ & wf & br & Spr & I \\
\hline
\end{tabular}




\begin{tabular}{|c|c|c|c|c|c|c|c|c|c|c|c|c|c|c|c|c|}
\hline Species & Short cut & M9 & M19 & M27 & M28 & M38 & M46 & M53 & M192 & MuS05 & MuA62 & EG & HP & WM & HM & BMC \\
\hline Bembidion properans & Bem prop & 2 & & & & 1 & 3 & & & 3 & 33 & (x) & af & di & (Spr) & I \\
\hline $\begin{array}{l}\text { Bembidion } \\
\text { quadrimaculatum }\end{array}$ & Bem quad & & & & 1 & & & & & & & (x) & af & $\mathrm{ma}^{*}$ & Spr & I \\
\hline Bembidion tetracolum & Bem tetr & 1 & & & & 21 & & 1 & & & & eu & af & di & Spr & I \\
\hline Bembidion varium & Bem vari & 1 & & 2 & 4 & & 1 & 4 & & & & $\mathrm{~h}$ & ba & ma* & Spr & I \\
\hline Blethisa multipunctata & Ble mult & 1 & & & 1 & & & 1 & & & & $\mathrm{~h}$ & re & $\mathrm{ma}^{*}$ & Spr & III \\
\hline Bradycellus csikii & Bra csik & & & & & 4 & & & & & & (x) & $\mathrm{fa}$ & di & (Aut) & I \\
\hline Calathus erratus & Cal erra & 2 & & 4 & 1 & & 1 & 1 & & 11 & 42 & $\mathrm{x}$ & $\mathrm{dg}$ & di & (Aut) & III \\
\hline Calathus fuscipes & Cal fusc & 2 & 2 & & 3 & & 1 & & & 195 & 168 & $(\mathrm{x})(\mathrm{f})$ & $\mathrm{fa}$ & di & (Aut) & III \\
\hline Calathus melanocephalus & Cal mela & 2 & 5 & & & & 9 & & & 9 & 12 & (x) & fa & di & (Aut) & II \\
\hline Carabus auratus & Car aura & 33 & 20 & 12 & 22 & 20 & 34 & 15 & & 214 & 435 & $(\mathrm{x})$ & af & br & $\mathrm{Spr}$ & $\mathrm{V}$ \\
\hline Carabus granulatus & Car gran & 96 & 17 & 63 & 10 & 20 & 15 & 15 & 1 & & 2 & $h(f)$ & wf & $\mathrm{di}$ & Spr & IV \\
\hline Carabus nemoralis & Car nemo & & 1 & & & & 6 & & & 5 & & $(\mathrm{~h})(\mathrm{f})$ & $\mathrm{mf}$ & br & (Spr) & $\mathrm{V}$ \\
\hline $\begin{array}{l}\text { Carabus violaceus } \\
\text { violaceus }\end{array}$ & Car viol & & & & & 1 & & & & & & $(\mathrm{x}) \mathrm{f}$ & mdf & br & (Aut) & $\mathrm{V}$ \\
\hline Chlaenius nigricornis & Chl nigr & & & 8 & 1 & & & 4 & & & & $\mathrm{~h}$ & wm & ma* & Spr & III \\
\hline Chlaenius tristis & Chl tris & & & & & 2 & 1 & & & & & $\mathrm{~h}$ & re & $\mathrm{ma}^{*}$ & Spr & III \\
\hline Clivina fossor & Cli foss & 58 & 30 & 21 & 15 & 2 & 106 & 2 & & 29 & 1 & $\mathrm{eu}$ & af & $\mathrm{di}^{*}$ & Spr & I \\
\hline Demetrias monostigma & Dem mono & 1 & & & & 2 & & & & & & $\mathrm{~h}$ & re & di & Spr & I \\
\hline Diachromus germanus & Dia germ & & & 1 & & 5 & & & & & & $\mathrm{~h}$ & wm & $\mathrm{ma}$ & (Spr) & III \\
\hline Dicheirotrichus rufithorax & Dic rufi & 1 & & & & & & & & & & $(\mathrm{x})$ & $\mathrm{fa}$ & $\mathrm{ma}^{*}$ & $\mathrm{Spr}$ & I \\
\hline Dyschirius globosus & Dys glob & 36 & 193 & 36 & 19 & 3 & 21 & 95 & & 8 & & $h(f)$ & wf & di & Spr & I \\
\hline Elaphrus cupreus & Ela cupr & 1 & 3 & 17 & 5 & 21 & 1 & 29 & & & & $h(f)$ & wf & ma* & Spr & II \\
\hline Elaphrus riparius & Ela ripa & 1 & 1 & & 1 & 10 & & 4 & & & & $\mathrm{~h}$ & ba & $\mathrm{ma}^{*}$ & Spr & I \\
\hline Harpalus affinis & Har affi & 2 & 1 & 1 & & 1 & 119 & 8 & & 28 & 67 & (x) & af & $\mathrm{ma}^{*}$ & Spr & III \\
\hline Harpalus autumnalis & Har autu & & & 1 & & & & & & & & $\mathrm{x}$ & $\mathrm{dg}$ & di & (Spr) & II \\
\hline Harpalus distinguendus & Har dist & 2 & & & 2 & & 3 & & & & & (x) & af & $\mathrm{ma}^{*}$ & (Spr) & III \\
\hline
\end{tabular}




\begin{tabular}{|c|c|c|c|c|c|c|c|c|c|c|c|c|c|c|c|c|}
\hline Species & Short cut & M9 & M19 & M27 & M28 & M38 & M46 & M53 & M192 & MuS05 & MuA62 & EG & HP & WM & HM & BMC \\
\hline Harpalus flavescens & Har flav & & & & & & 2 & & & & & $\mathrm{x}$ & $\mathrm{dg}$ & $\mathrm{ma}$ & (Aut) & III \\
\hline Harpalus froelichii & Har froe & & 1 & & 1 & & 1 & & & 1 & & $\mathrm{x}$ & $\mathrm{dg}$ & $\mathrm{ma}^{*}$ & Spr & III \\
\hline Harpalus latus & Har latu & 3 & & 1 & 4 & & 57 & 1 & & 3 & & (h) & pa & $\mathrm{ma}^{*}$ & Irr & III \\
\hline Harpalus luteicornis & Har lute & & 2 & 1 & 1 & & 40 & & & 4 & & (x) & $\mathrm{fa}$ & $\mathrm{ma}$ & Spr & I \\
\hline Harpalus pumilus & Har pumi & & & & & & & & & & & $\mathrm{x}$ & $\mathrm{dg}$ & di & (Spr) & I \\
\hline Harpalus rubripes & Har rubr & & & & & & 1 & & & 6 & & $\mathrm{x}$ & fa & $\mathrm{ma}^{*}$ & Irr & III \\
\hline Harpalus rufipes & Har rufi & 39 & 4 & 29 & 9 & 1 & 401 & 19 & 2 & 25 & 157 & (x) & af & $\mathrm{ma}^{*}$ & (Aut) & III \\
\hline Harpalus serripes & Har serr & & & & & & 2 & & & & & $\mathrm{x}$ & $\mathrm{dg}$ & $\mathrm{ma}^{*}$ & $\mathrm{Spr}$ & III \\
\hline Harpalus servus & Har serv & & 2 & & 3 & & 1 & & & 2 & & $\mathrm{x}$ & $\mathrm{dg}$ & $\mathrm{ma}$ & Spr & III \\
\hline Harpalus signaticornis & Har sign & & & 1 & & 1 & 4 & 1 & & 2 & 11 & (x) & af & $\mathrm{ma}$ & Spr & I \\
\hline Harpalus smaragdinus & Har smar & 6 & 2 & 1 & 5 & & 43 & 2 & & 8 & 10 & $\mathrm{x}$ & $\mathrm{dg}$ & $\mathrm{ma}^{*}$ & (Aut) & III \\
\hline Harpalus tardus & Har tard & 1 & & & 2 & & 2 & & & 2 & & $(\mathrm{x})$ & $\mathrm{fa}$ & $\mathrm{ma}^{*}$ & $(\mathrm{Spr})$ & III \\
\hline Leistus ferrugineus & Lei ferr & 2 & & & 2 & & & & & & & $(\mathrm{x})(\mathrm{f})$ & mdf & br & Aut & I \\
\hline Leistus terminatus & Lei term & 2 & 3 & 3 & 2 & & 1 & 5 & & & & $h(f)$ & mo & di & Aut & I \\
\hline Limodromus assimilis & Lim assi & & & & & & 3 & & & & & $h(f)$ & wf & $\mathrm{ma}^{*}$ & Spr & III \\
\hline Loricera pilicornis & Lor pili & 33 & 11 & 22 & 15 & 4 & 12 & 24 & & 8 & 37 & (h)(f) & af & $\mathrm{ma}^{*}$ & (Spr) & II \\
\hline Microlestes maurus & Mic maur & & & & & & & & & 2 & & $(\mathrm{x})$ & $\mathrm{fa}$ & di & $\mathrm{Spr}$ & I \\
\hline Microlestes minutulus & Mic minu & & 1 & & 2 & & & & & & 1 & $(\mathrm{x})$ & $\mathrm{fa}$ & $\mathrm{ma}^{*}$ & $\mathrm{Spr}$ & I \\
\hline Nebria brevicollis & Neb brev & & & 4 & & 4 & & 1 & & 1 & & (h)(f) & $\mathrm{mf}$ & $\mathrm{ma}^{*}$ & (Aut) & III \\
\hline Notiophilus palustris & Not palu & 4 & & 4 & & 1 & 4 & & & & 6 & $\mathrm{hf}$ & wf & $\mathrm{di}$ & Spr & I \\
\hline Oodes helopioides & Ood helo & 137 & 23 & 41 & 55 & 21 & 8 & 81 & 7 & & & $\mathrm{~h}$ & $\mathrm{re}$ & ma* & Spr & II \\
\hline Oxypselaphus obscurus & Oxy obsc & 161 & 7 & 211 & 21 & 5 & 14 & 7 & & & & $h(f)$ & $\mathrm{wf}$ & $\mathrm{di}$ & Irr & I \\
\hline Panagaeus cruxmajor & Pan crux & & & & 1 & & & & & & & $\mathrm{~h}$ & re & $\mathrm{ma}$ & Spr & II \\
\hline Patrobus atrorufus & Pat atro & 4 & 3 & 43 & & 29 & 2 & 7 & & & 1 & $h(f)$ & $\mathrm{wf}$ & di & (Aut) & II \\
\hline Poecilus cupreus & Poe cupr & 22 & 1 & 1 & & & 68 & 1 & & 38 & 75 & (h) & af & $\mathrm{ma}^{*}$ & Spr & III \\
\hline Poecilus punctulatus & Poe punc & & & & & & 3 & & & & 85 & (x) & af & $\mathrm{ma}$ & Spr & III \\
\hline
\end{tabular}




\begin{tabular}{|c|c|c|c|c|c|c|c|c|c|c|c|c|c|c|c|c|}
\hline Species & Short cut & M9 & M19 & M27 & M28 & M38 & M46 & M53 & M192 & MuS05 & MuA62 & EG & HP & WM & HM & BMC \\
\hline Poecilus versicolor & Poe vers & 32 & 20 & 12 & 13 & & 278 & 2 & & 822 & 198 & (h) & af & ma* & Spr & III \\
\hline Pterostichus diligens & Pte dili & 7 & 10 & 11 & 7 & 3 & 11 & 11 & 4 & & & $\mathrm{~h}$ & mo & $\mathrm{di}$ & (Spr) & I \\
\hline Pterostichus melanarius & Pte mela & 340 & 18 & 71 & 17 & & 65 & 67 & & 34 & 82 & $\mathrm{eu}$ & $\mathrm{pa}$ & $\mathrm{di}$ & (Aut) & IV \\
\hline Pterostichus minor & Pte mino & 5 & 13 & 7 & 59 & 1 & 14 & 8 & 13 & & & $h(f)$ & mo & di & (Spr) & II \\
\hline Pterostichus niger & Pte nige & 59 & 49 & 39 & 11 & 16 & 24 & 6 & & 4 & 3 & (h)(f) & $\mathrm{mf}$ & $\mathrm{di}^{*}$ & (Aut) & IV \\
\hline Pterostichus nigrita & Pte nigr & 237 & 43 & 76 & 37 & 3 & 165 & 112 & 33 & 5 & & $h(f)$ & wf & $\mathrm{ma}^{*}$ & (Spr) & III \\
\hline $\begin{array}{l}\text { Pterostichus } \\
\text { oblongopunctatus }\end{array}$ & Pte oblo & 36 & 4 & 16 & 3 & 3 & & 22 & 25 & & 1 & $(x) f$ & mdf & di & (Spr) & III \\
\hline Pterostichus rhaeticus & Pte rhae & 20 & & 12 & 1 & & 4 & 6 & & & & $\mathrm{~h}$ & mo & ma & (Spr) & III \\
\hline Pterostichus strenииs & Pte stre & 13 & 14 & 24 & 9 & 2 & 17 & 28 & 1 & & & (h)f & $\mathrm{mf}$ & di & Spr & I \\
\hline Pterostichus vernalis & Pte vern & 6 & 5 & 17 & 6 & 9 & 17 & 14 & 7 & 4 & & $\mathrm{~h}$ & wm & $\mathrm{di}$ & $\mathrm{Spr}$ & I \\
\hline Stenolophus mixtus & Ste mixt & 6 & 28 & 47 & 55 & 15 & 16 & 49 & & & & $\mathrm{~h}$ & re & $\mathrm{ma}^{*}$ & Spr & I \\
\hline $\begin{array}{l}\text { Stenolophus } \\
\text { skrImshIrranus }\end{array}$ & Ste skri & & 29 & 52 & 15 & 5 & 1 & 27 & & & & $\mathrm{~h}$ & re & ma & Spr & I \\
\hline Stenolophus teutonus & Ste teut & 1 & 1 & 2 & 2 & & 9 & & & & & $\mathrm{~h}$ & $\mathrm{ba}$ & ma & Spr & I \\
\hline Stomis pumicatus & Sto pumi & 3 & & & 1 & & & & & & & $\mathrm{~h}$ & wm & br & Spr & II \\
\hline Syntomus truncatellus & Syn trun & & & & & & 1 & & & 1 & 1 & $(\mathrm{x})$ & fa & di & Spr & I \\
\hline Synuchus vivalis & Syn viva & 4 & & & 1 & & 1 & 1 & & 4 & & $(\mathrm{x})(\mathrm{f})$ & $\mathrm{fa}$ & di & Aut & II \\
\hline Trechus obtusus & Tre obtu & 50 & 10 & 5 & 5 & & 25 & 3 & & 4 & 5 & $(\mathrm{~h})(\mathrm{f})$ & $\mathrm{fa}$ & $\mathrm{di}$ & (Aut) & I \\
\hline Trechus quadristriatus & Tre quad & 23 & 2 & & & & 1 & & & & 2 & $(\mathrm{x})$ & af & ma* & (Aut) & I \\
\hline Trichocellus placidus & Tri plac & & & 1 & & & & & & & & $\mathrm{~h}$ & re & $\mathrm{ma}$ & Spr & I \\
\hline Zabrus tenebrioides & Zab tene & & & & & & & 2 & & & 12 & $(\mathrm{x})$ & af & $\mathrm{ma}^{*}$ & Aut & III \\
\hline
\end{tabular}


Table A3: A list of spider species including the short cuts used in Figs. 2, the total number of individuals caught in the trapping period and details on biology, ecological and functional groups.

$\mathrm{EG}=$ ecological group: $\mathrm{h}=$ hygrophilic,$(\mathrm{h})=$ moderately hygrophilic, $\mathrm{x}=$ xerophilic, $(\mathrm{x})=$ moderately xerophilic, eu= eurytopic, $\mathrm{hf}=\mathrm{hygrophilic}$ and in forests, $\mathrm{h}(\mathrm{f})=$ hygrophilic in open sites and in forests, $(\mathrm{h}) \mathrm{f}=$ moderately hygrophilic and in forests, $(\mathrm{h})(\mathrm{f})=$ moderately hygrophilic and predominantly in forests $(\mathrm{x}) \mathrm{f}=$ moderately xerophilic and in forests, $(x)(f)=$ moderately xerophilic and predominantly in forests (summarized as ombrophilic in Table 4); $\mathrm{HP}=$ habitat preference: af $=$ arable fields; fa $=$ fallows ; wet, open habitats (as summarized in Fig. 3): $b a=$ banks, mo $=$ moors, $r e=$ reeds, woh $=$ wet, open habitats; meadows and pastures $($ as summarized in Fig. 3): mea= meadows in general, wm= wet meadows, pa = pastures; dry, open habitats (as summarized in Fig. 3): Cah= Calluna heaths, dg= dry grassAutnd, doh= dry, open habitats; oha $=$ open habitats; forests (as summarized in Fig. 3 ): $\mathrm{wf}=$ wet forests, $\mathrm{mf}=$ moist forests, $\mathrm{mdf}=$ moderately dry forests, $\mathrm{mdfe}=$ moderately dry forest edges, pif $=$ pioneer forests, fo= forests in general; $\mathrm{BMC}=$ body mass class: $\mathrm{I}=\langle 1 \mathrm{mg}, \mathrm{II}=1-4.9 \mathrm{mg}, \mathrm{III}=5-9.9 \mathrm{mg}, \mathrm{IV}=10-20 \mathrm{mg} ; \mathrm{V}=>20$ $\mathrm{mg}$; Ball= Ballooning observed. For the abbreviations for the plots: see Chapter 2.1.

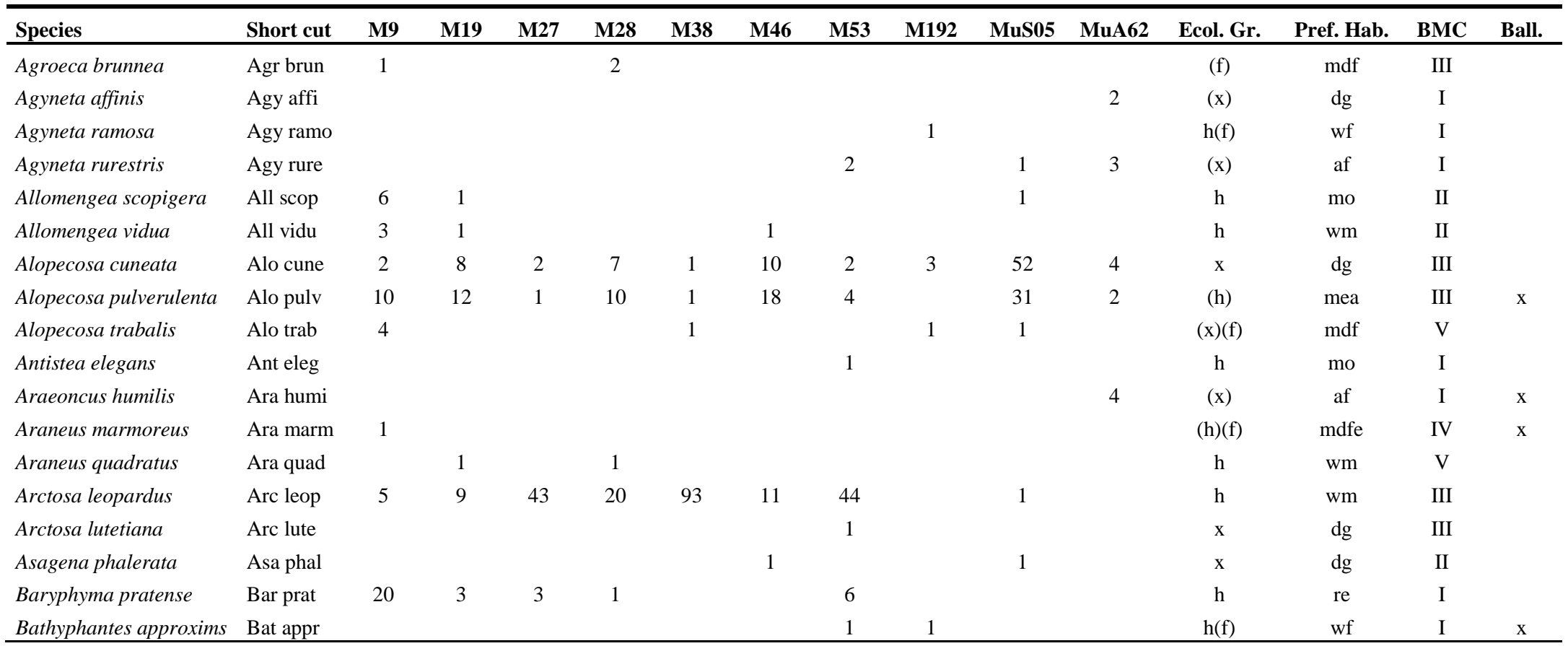




\begin{tabular}{|c|c|c|c|c|c|c|c|c|c|c|c|c|c|c|c|}
\hline Species & Short cut & M9 & M19 & M27 & M28 & M38 & M46 & M53 & M192 & MuS05 & MuA62 & Ecol. Gr. & Pref. Hab. & BMC & Ball. \\
\hline Bathyphantes gracilis & Bat grac & & & & & & & 1 & & & & (x) & af & I & $\mathrm{x}$ \\
\hline Bathyphantes nigrinus & Bat nigr & & & & 1 & & & & & & & $\mathrm{hf}$ & wf & I & $\mathrm{x}$ \\
\hline Bathyphantes parvulus & Bat parv & & & & 2 & & & & & & & (x) & $\mathrm{fa}$ & I & \\
\hline Centromerus dilutus & Cen dilu & & & & 1 & & & & & & & (h)f & $\mathrm{mf}$ & I & \\
\hline Ceratinella brevipes & Cer brep & 1 & & 1 & 3 & & & 1 & 1 & 1 & & $\mathrm{~h}$ & wm & I & \\
\hline Ceratinopsis stativa & Cer stat & & & & & & 1 & & & & & (h) & wm & I & \\
\hline Clubiona diversa & Clu dive & 1 & & & 1 & & & & & & & $\mathrm{~h}$ & wm & II & \\
\hline Clubiona fIrrisia & Clu fris & 1 & & & & & & & & & & $\mathrm{x}$ & $\mathrm{dg}$ & II & \\
\hline Clubiona lutescens & Clu lute & & & & 1 & 1 & & & & & & $\mathrm{hf}$ & wf & II & \\
\hline Clubiona phragmitis & Clu phra & 11 & 1 & 1 & 6 & 2 & 2 & 1 & 1 & & & $\mathrm{~h}$ & re & III & \\
\hline Clubiona reclusa & Clu recl & 3 & 2 & 1 & 5 & 3 & 2 & 3 & & 1 & & (x) & $\mathrm{fa}$ & II & \\
\hline Clubiona stagnatilis & Clu stag & 4 & 3 & 3 & 1 & & 7 & 3 & & 1 & & $\mathrm{~h}$ & re & III & $\mathrm{x}$ \\
\hline Clubiona terrestris & Clu terr & & & & & 1 & & & & 1 & & $(\mathrm{x})(\mathrm{f})$ & mdf & III & \\
\hline $\begin{array}{l}\text { Clubiona trivialis } \\
\text { Dicymbium nigrum }\end{array}$ & Clu triv & & & & 2 & & & & & & & $(\mathrm{x})(\mathrm{f})$ & mdfe & II & \\
\hline brevisetosum & Dic brev & & & & 1 & & & & & & & $(\mathrm{x})$ & pa & I & $\mathrm{x}$ \\
\hline Diplocephalus permixtus & Dip perm & & & & & 1 & & & & & & $h(f)$ & wf & I & \\
\hline Diplostyla concolor & Dip conc & 2 & 1 & 4 & 26 & 2 & 4 & 4 & & & & (h)(f) & $\mathrm{mf}$ & I & $\mathrm{x}$ \\
\hline Dismodicus elevatus & Dis elev & & & & & 1 & & & & & & $(\mathrm{x}) \mathrm{f}$ & mdf & I & \\
\hline Drassyllus lutetianus & Drs lute & 102 & 29 & 43 & 50 & 10 & 92 & 31 & 5 & 39 & 7 & (h) & af & II & \\
\hline Drassyllus praeficus & Drs prae & & & 1 & 1 & & & & & & & $\mathrm{x}$ & $\mathrm{dg}$ & II & \\
\hline Drassyllus pusillus & Drs pusi & & & 2 & 2 & & & & & 10 & 3 & (x) & $\mathrm{fa}$ & II & \\
\hline Enoplognatha caricis & Eno cari & & & & & & & & 1 & & & $\mathrm{~h}$ & re & II & $\mathrm{x}$ \\
\hline Enoplognatha oelandica & Eno oela & 1 & & & & & & & & & & $\mathrm{x}$ & $\mathrm{dg}$ & I & \\
\hline Enoplognatha thoracica & Eno thor & & & 1 & 1 & & & & & 1 & & $(\mathrm{x})(\mathrm{f})$ & doh & II & $\mathrm{x}$ \\
\hline Erigone atra & Eri atra & 16 & 14 & 13 & 11 & 10 & 28 & 27 & 8 & 11 & 305 & (h) & af & I & $\mathrm{x}$ \\
\hline Erigone dentipalpis & Eri dent & 2 & 3 & 1 & 11 & 1 & 5 & 2 & 1 & 3 & 121 & $(\mathrm{x})$ & af & I & $\mathrm{x}$ \\
\hline
\end{tabular}




\begin{tabular}{|c|c|c|c|c|c|c|c|c|c|c|c|c|c|c|c|}
\hline Species & Short cut & M9 & M19 & M27 & M28 & M38 & M46 & M53 & M192 & MuS05 & MuA62 & Ecol. Gr. & Pref. Hab. & BMC & Ball. \\
\hline Erigone longipalpis & Eri long & & & & & & & & & & 1 & $(\mathrm{x})$ & af & I & $\mathrm{x}$ \\
\hline Erigonella ignobilis & Eri igno & & 1 & & & & & & 1 & & & $\mathrm{~h}$ & mo & I & \\
\hline Euophrys frontalis & Euo fron & 1 & & & & & & & & & & $(\mathrm{x})(\mathrm{f})$ & mdf & II & \\
\hline Euryopis flavomaculata & Eur flav & 1 & & & 9 & & & & & & & $(\mathrm{x})(\mathrm{f})$ & mdfe & II & \\
\hline $\begin{array}{l}\text { Gnathonarium dentatum } \\
\text { Gongylidiellum }\end{array}$ & Gna dent & 1 & 2 & & 1 & 1 & & 1 & & & & $\mathrm{~h}$ & woh & I & $\mathrm{x}$ \\
\hline latebricola & Gon late & & & & & & & 1 & & & & $(\mathrm{x})(\mathrm{f})$ & mdf & I & \\
\hline Gongylidiellum vivum & Gon vivu & & & & & & & & 2 & & & $\mathrm{~h}$ & mo & I & $\mathrm{x}$ \\
\hline Haplodrassus signifer & Hap signi & & & & & & 1 & & & 2 & & $\mathrm{x}$ & $\mathrm{fa}$ & III & \\
\hline $\begin{array}{l}\text { Heliophanus auratus } \\
\text { Hypomma }\end{array}$ & Hel aura & & & 1 & & & & & & & & $\mathrm{~h}$ & re & II & \\
\hline bituberculatum & Hyp bitu & & & & & & & 3 & & & & $\mathrm{~h}$ & re & I & $\mathrm{x}$ \\
\hline Hypomma fulvum & Hyp fulv & & & & & & & 1 & & & & $\mathrm{~h}$ & re & I & \\
\hline Liocranoeca striata & Lio stri & & & & & & 1 & & & & & (h)f & $\mathrm{mf}$ & II & \\
\hline Marpissa radiata & Mar radi & 1 & & & & & & & & & & $\mathrm{~h}$ & re & III & \\
\hline Micaria pulicaria & Mic puli & & 1 & 1 & 1 & & 1 & & & & & (x) & $\mathrm{fa}$ & II & \\
\hline Microlinyphia pusilla & Mic pusi & & & & & & & & & 1 & & $(\mathrm{x})$ & $\mathrm{fa}$ & II & \\
\hline Neottiura bimaculata & Neo bima & & & & 1 & & & & 1 & & & $(\mathrm{x})(\mathrm{f})$ & pif & I & \\
\hline Neriene clathrata & Ner clat & & & & 7 & & & 1 & & & & (h)f & $\mathrm{mf}$ & II & $\mathrm{x}$ \\
\hline Notioscopus sarcinatus & Not sarc & & & & & & & & 5 & & & $\mathrm{~h}$ & mo & I & \\
\hline Oedothorax apicatus & Oed apic & & 10 & & 8 & 4 & 6 & 7 & 5 & 1 & 66 & (x) & af & I & $\mathrm{x}$ \\
\hline Oedothorax fuscus & Oed fusc & & 5 & 5 & 6 & 11 & 2 & 4 & 1 & & 1 & $\mathrm{~h}$ & wm & I & $\mathrm{x}$ \\
\hline Oedothorax gibbosus & Oed gibb & & & 1 & 2 & 1 & 1 & 3 & 7 & & & $\mathrm{~h}$ & mo & I & $\mathrm{x}$ \\
\hline Oedothorax retusus & Oed retu & 2 & 18 & 12 & 15 & 21 & 7 & 51 & 7 & & 3 & (h) & wm & I & $\mathrm{x}$ \\
\hline Ozyptila praticola & Ozy prat & & & & & 1 & & & & & & $(\mathrm{x}) \mathrm{f}$ & mdf & I & \\
\hline Ozyptila trux & Ozy trux & 21 & 7 & 1 & 12 & 5 & 14 & 16 & 1 & 1 & 1 & $h(f)$ & wm & II & \\
\hline Pachygnatha clercki & Pac cler & 20 & 15 & 31 & 27 & 52 & 5 & 43 & & 10 & & $\mathrm{~h}$ & wm & II & $\mathrm{x}$ \\
\hline
\end{tabular}




\begin{tabular}{|c|c|c|c|c|c|c|c|c|c|c|c|c|c|c|c|}
\hline Species & Short cut & M9 & M19 & M27 & M28 & M38 & M46 & M53 & M192 & MuS05 & MuA62 & Ecol. Gr. & Pref. Hab. & BMC & Ball. \\
\hline Pachygnatha degeeri & Pac dege & & & 1 & 2 & & & 2 & & 51 & 7 & (x) & af & I & $\mathrm{x}$ \\
\hline Pardosa agrestis & Par agre & 32 & 14 & 13 & 29 & 8 & 161 & 5 & 1 & 190 & 81 & $(\mathrm{x})$ & af & III & \\
\hline Pardosa amentata & Par amen & 83 & 39 & 282 & 249 & 121 & 163 & 149 & 13 & 6 & 5 & (h) & wm & II & $\mathrm{x}$ \\
\hline Pardosa monticola & Par mont & & & & 1 & & & & & & & $\mathrm{x}$ & $\mathrm{dg}$ & II & $\mathrm{x}$ \\
\hline Pardosa paludicola & Par pald & 10 & 15 & 4 & 12 & 6 & 44 & 12 & 1 & & 1 & $\mathrm{~h}$ & re & II & \\
\hline Pardosa palustris & Par palu & 1156 & 872 & 953 & 1056 & 562 & 1596 & 818 & 81 & 554 & 103 & $(\mathrm{x})$ & oha & III & $\mathrm{x}$ \\
\hline Pardosa prativaga & Par prat & 47 & 22 & 22 & 44 & 6 & 26 & 18 & 7 & 1136 & 70 & $\mathrm{~h}$ & wm & II & $\mathrm{x}$ \\
\hline Pardosa pullata & Par pull & 5 & 2 & 4 & 5 & 4 & 6 & 1 & 2 & 5 & & $\mathrm{~h}$ & woh & II & $\mathrm{x}$ \\
\hline Pelecopsis parallela & Pel para & & & & & & & & & 2 & & (x) & $\mathrm{dg}$ & $\mathrm{I}$ & \\
\hline Phylloneta impressa & Phy impr & & 1 & & & & & & & & & $(\mathrm{x})$ & $\mathrm{fa}$ & II & $\mathrm{x}$ \\
\hline PIrrata pIrraticus & PIrr pIrra & 38 & 12 & 18 & 46 & 14 & 72 & 54 & 4 & 1 & 1 & $\mathrm{~h}$ & mo & II & $\mathrm{x}$ \\
\hline PIrrata piscatorius & PIrr pisc & 3 & 1 & 8 & 9 & 3 & 2 & 10 & 11 & & & $\mathrm{~h}$ & mo & III & \\
\hline PIrrata tenuitarsis & PIrr tenu & 3 & & 2 & 1 & & & 6 & 8 & & & $\mathrm{~h}$ & mo & II & \\
\hline PIrratula hygrophila & PIrr hygr & 164 & 88 & 361 & 449 & 252 & 173 & 560 & 330 & 16 & 1 & $h(f)$ & wf & II & \\
\hline PIrratula latitans & PIrr lati & 19 & 7 & 14 & 7 & 13 & 3 & 22 & 398 & & 1 & $\mathrm{~h}$ & mo & II & \\
\hline Pisaura mIrrabilis & Pis mIrra & 3 & & 1 & 1 & 1 & 5 & 1 & 1 & 3 & & $(\mathrm{x})$ & fa & $\mathrm{V}$ & $\mathrm{x}$ \\
\hline Pocadicnemis juncea & Poc junc & & & 3 & 2 & & 1 & 1 & 9 & & & $\mathrm{~h}$ & woh & $\mathrm{I}$ & \\
\hline Pocadicnemis pumila & Poc pumi & & & & & & & & 1 & & & $(h)(f)$ & $\mathrm{mf}$ & I & \\
\hline Porrhomma pygmaeum & Por pygm & & & 1 & 1 & 1 & 1 & 1 & 1 & & & $h(f)$ & wf & I & $\mathrm{x}$ \\
\hline Robertus arundineti & Rob arun & & & & & & & 1 & 1 & 1 & & $h(f)$ & mo & I & $\mathrm{x}$ \\
\hline Savignia frontata & Sav fron & & 1 & & & & & & & & & $\mathrm{~h}$ & wm & I & $\mathrm{x}$ \\
\hline Tallusia experta & Tal expe & 3 & 2 & 1 & 3 & 1 & 4 & 1 & & 1 & & (h) & pa & I & $\mathrm{x}$ \\
\hline Tapinocyba praecox & Tap prae & & & & 2 & & 1 & & & & & $\mathrm{x}$ & $\mathrm{dg}$ & I & \\
\hline Tenuiphantes tenuis & Ten tenu & & 1 & 1 & & & 1 & & & & & $(\mathrm{x})$ & pa & I & $\mathrm{x}$ \\
\hline Tetragnatha dearmata & Tet dear & & 1 & 1 & & 1 & & & & & & $h(f)$ & wf & III & \\
\hline Thanatus striatus & Tha stri & 14 & & & & & 2 & 1 & & & & $\mathrm{~h}$ & mo & II & \\
\hline
\end{tabular}




\begin{tabular}{|c|c|c|c|c|c|c|c|c|c|c|c|c|c|c|c|}
\hline Species & Short cut & M9 & M19 & M27 & M28 & M38 & M46 & M53 & M192 & MuS05 & MuA62 & Ecol. Gr. & Pref. Hab. & BMC & Ball. \\
\hline Theridion varians & The vari & & & & 1 & & & & & & & $(\mathrm{x}) \mathrm{f}$ & mdf & I & \\
\hline Tibellus oblongus & Tib oblo & & & & & & 1 & & & & & $(\mathrm{x})$ & $\mathrm{fa}$ & III & \\
\hline Tiso vagans & Tis vaga & & & & & & & & & 1 & & (h) & wm & $\mathrm{I}$ & $\mathrm{x}$ \\
\hline Trochosa ruricola & Tro ruri & 13 & 6 & 29 & 17 & 11 & 107 & 19 & 16 & 59 & 1 & (h) & $\mathrm{fa}$ & IV & $\mathrm{x}$ \\
\hline Trochosa spinipalpis & Tro spin & 1 & 1 & 6 & 2 & 1 & & 1 & 36 & & & $h(f)$ & mo & IV & \\
\hline Trochosa terricola & Tro terr & & & & 1 & & & & & & & $(h)(f)$ & fo & IV & $\mathrm{x}$ \\
\hline Troxochrus scabriculus & Tro scab & 1 & & & & & & & & & & $(\mathrm{x})$ & doh & I & \\
\hline $\begin{array}{l}\text { Walckenaeria antica } \\
\text { Walckenaeria }\end{array}$ & Wal anti & 1 & & & & & & & & & & (x) & $\mathrm{fa}$ & I & $\mathrm{x}$ \\
\hline atrotibialis & Wal atro & 2 & & & & & & & 3 & & & $h(f)$ & wf & I & \\
\hline Walckenaeria cucullata & Wal cuc & & & & & & & & & 1 & & $(\mathrm{x}) \mathrm{f}$ & mdf & I & \\
\hline Walckenaeria cuspidata & Wal cusp & & 1 & & 1 & & & & & & & $h(f)$ & wf & I & $\mathrm{x}$ \\
\hline $\begin{array}{l}\text { Walckenaeria kochi } \\
\text { Walckenaeria }\end{array}$ & Wal koch & 1 & 1 & & & & & & 11 & & & $\mathrm{~h}$ & mo & I & \\
\hline monoceros & Wal mono & 1 & & & & & & 1 & & & & $(\mathrm{x}) \mathrm{f}$ & mdf & I & \\
\hline Walckenaeria nudipalpis & Wal nudi & 2 & 1 & & 2 & & 2 & 1 & & & & $\mathrm{~h}$ & mo & I & $\mathrm{x}$ \\
\hline Walckenaeria obtusa & Wal obtu & & & & & 1 & & & & & & $(x) f$ & mdf & II & \\
\hline Walckenaeria unicornis & Wal unic & & & & & & & 1 & 1 & & & $\mathrm{~h}$ & woh & I & \\
\hline Walckenaeria vigilax & Wal vigi & & & & 1 & & & 2 & 3 & & & $\mathrm{~h}$ & mo & I & $\mathrm{x}$ \\
\hline Xerolycosa miniata & Xer mini & & & & 1 & & & & & 18 & & $\mathrm{x}$ & $\mathrm{dg}$ & II & \\
\hline Xysticus audax & Xys auda & & & & & 1 & & & & & 1 & $\mathrm{x}$ & Cah & II & \\
\hline Xysticus cristatus & Xys cris & 2 & & 3 & 2 & 1 & 1 & 3 & & 9 & & (x) & $\mathrm{fa}$ & II & $\mathrm{x}$ \\
\hline Xysticus kochi & Xys koch & 7 & 6 & 1 & 2 & & 3 & 1 & & 63 & 33 & $\mathrm{x}$ & $\mathrm{dg}$ & II & $\mathrm{x}$ \\
\hline Xysticus ulmi & Xys ulmi & 35 & 7 & 4 & 8 & 2 & 12 & 6 & 1 & 3 & 3 & $\mathrm{~h}$ & woh & II & $\mathrm{x}$ \\
\hline Zelotes subterraneus & Zel subt & 1 & & 1 & & 1 & & & 2 & & & $(\mathrm{x})(\mathrm{f})$ & mdf & III & \\
\hline Zora spinimana & Zor spin & 7 & 6 & 3 & 8 & 1 & 7 & & 2 & & 3 & (h) & $\mathrm{fa}$ & II & $\mathrm{x}$ \\
\hline
\end{tabular}

